\title{
Invited review paper: Some outstanding issues in the study of great megathrust earthquakes - the Cascadia example
}

Kelin Wang ${ }^{\mathrm{a}^{*}}$ and Anne M. Tréhu ${ }^{\mathrm{b}}$

${ }^{a}$ Pacific Geoscience Centre, Geological Survey of Canada, Natural Resources Canada, 9860

West Saanich Road, Sidney, British Columbia, Canada (email: Kelin.Wang@Canada.ca)

${ }^{\mathrm{b}}$ College of Oceanic and Atmospheric Sciences, Oregon State University, Corvallis, Oregon 97331-5503, USA

* Corresponding Author

Keywords: Megathrust earthquakes, subduction zone, Cascadia 


\begin{abstract}
Because of a combination of new observational tools and a flurry of large megathrust earthquakes in the past decade, tremendous progress has been made in recent years towards understanding the process of great subduction earthquakes at Cascadia and other subduction zones around the world. This review article attempts to clarify some of widely used geodynamic concepts and identify the most important scientific questions for future research related to megathrust behaviour. It is important to specify how the megathrust seismogenic zone has been defined when comparing data and models. Observations and concepts currently used to define the seismogenic zone include: A) the stability transition in rate-state dependent friction; B) the slip zone of large interplate earthquakes; C) the distribution of small-medium earthquakes; and D) the geodetically-determined zone of fault locking. Land-based geodetic measurements indicate that the Cascadia megathrust is locked to some extent, but the degree of locking is not well constrained. The near absence of detectable interplate seismicity, with the exception of a segment near $44.5^{\circ} \mathrm{N}$ and near the Mendocino Triple Junction, is presently interpreted to indicate full locking along most of Cascadia. Resolving the locking state requires seafloor geodetic measurements. The slip behaviour of the shallowest segment of the megathrust and its tsunamigenic potential are complex and variable. Structural studies combined with modeling have the potential to improve our understanding of the signature left in the structure by the slip history. For several reasons, but mostly because of interseismic viscoelastic stress relaxation, the downdip limit of megathrust locking cannot be reliably constrained by geodetic data. Independent information is needed on the composition and thermal state of fault zone materials. The spatial relationship between the seismogenic zone and the zone of Episodic Tremor and Slip (ETS) remains controversial. Observations from the Nankai subduction zone and the San Andreas Fault suggest that ETS does not mark a simple spatial transition from seismic to aseismic behaviour and that multiple transitions may be present because of petrological and rheological changes with depth. Coseismic rupture in the AD 1700 Cascadia earthquake has been shown to vary along strike, and it is important to investigate whether the position of boundaries between high slip and low slip are stationary with time (and therefore probably geologically controlled) and are reflected in current interseismic locking of the megathrust.
\end{abstract}




\section{Contents}

1. Introduction

2. What is the seismogenic zone?

2.1. Defining the "seismogenic zone"

2.1.1. Definition A: based on rate-state frictional properties

2.1.2. Definition B: based on observed rupture of large earthquakes

2.1.3. Definition $\mathrm{C}$ : based on distribution of small and medium earthquakes

2.1.4. Definition D: based on geodetically inferred interseismic locking

2.2. A brief history of Cascadia seismogenic zone models

3. Locking or creeping?

3.1. Relevance of offshore seismicity

3.2. Importance of seafloor geodesy

4. Slip behaviour of the shallowest segment of the megathrust and tsunami generation

4.1. Buried rupture and splay fault scenarios

4.2. Trench-breaching rupture

4.3. Tsunami earthquakes

5. Downdip limit of the seismogenic zone

5.1. Geodetic interseismic deformation cannot constrain the downdip limit

5.1.1. Stress shadow

5.1.2. Temporal changes in locking width

5.1.3. Viscoelastic effects and "interseismic" stress relaxation

5.1.4. Upper plate deformation and block models

5.1.5. Interseismic vertical deformation

5.2. New questions about the thermal limit and fault gouge rheology

5.2.1. The role of gabbro

5.2.2. Hydrothermal cooling of the subducting crust

6. Controversial relationship between the seismogenic zone and ETS

6.1. Does updip limit of ETS correspond to downdip limit of seismogenic zone?

6.2. ETS and the mantle wedge corner

7. Along-strike variations of slip behaviour

8. Summary 


\section{Introduction}

Many populated coastal areas around the world, such as part of the west coast of North America, where the Juan de Fuca plate is subducting along the Cascadia subduction zone, are under the threat of future great subduction earthquakes and their tsunamis. Strategies for mitigating risks need to keep up with the rapidly evolving knowledge of subduction zone geodynamics and megathrust slip behaviour. Revolutions in seismic and geodetic monitoring have led to discoveries that raise new scientific questions and provide tantalizing glimpses into new approaches for risk management. Recent great earthquakes such as the $2004 \mathrm{M}_{\mathrm{w}}=9.2$ Sumatra and $2011 \mathrm{M}_{\mathrm{w}}=9.0$ Tohoku-oki earthquakes have resulted in a number of scientific surprises. In this review article, we examine various scientific concepts and models that are being used to guide risk mitigation practices. In contrast to most review articles, our emphasis is on what is poorly known and on how to proceed to improve our knowledge. We do not attempt to review all the outstanding issues in this vast research field but only discuss those we deem to be the most urgent for improving hazard assessment and risk mitigation. Although the geographical focus is Cascadia, much of the discussion is applicable to other subduction zones.

There has never been an instrumentally recorded large megathrust earthquake in Cascadia. Knowledge of the size and recurrence pattern of past megathrust earthquakes comes mostly from coastal geological studies (Atwater, 1987) and marine turbidite records (Adams, 1990; Goldfinger et al., 2012). Although some of the specific conclusions of these studies are still contentious (Atwater et al., 2014; Goldfinger et al., 2014), it is widely accepted that Cascadia has produced great earthquakes that rupture most of the margin on average about every five centuries. That the most recent $\mathrm{M}_{\mathrm{w}} \sim 9$ Cascadia earthquake occurred on 26 January 1700 is indicated by an “orphan" tsunami in Japanese historical records (Satake et al., 2003). If the megathrust is assumed to have been fully locked since that time, $\sim 15 \mathrm{~m}$ of slip deficit has accumulated based on the MORVEL Juan de Fuca/North America plate vector (DeMets et al., 2010). Without instrumental records of a great earthquake, our understanding of Cascadia megathrust earthquake cycles and their impact is based on interpretation of the paleoseismic and paleo-tsunami evidence, 
modeling of modern geodetic observations of interseismic deformation, very limited and localized seismicity, episodic tremor and slip (ETS) observed down-dip of the nominal locked zone, theoretical inferences about the megathrust's slip behaviour, and what we can infer from comparative studies with other subduction zones where great earthquakes have been instrumentally recorded.

To apply knowledge gained from other subduction zones to Cascadia and vice versa, we must recognize Cascadia's special or unique characteristics. Appreciating these characteristics highlights why Cascadia serves as an end-member representative for some margins and a contrasting example for others.

1) Because of the young age $(<15 \mathrm{Ma})$ of the subducting oceanic plate and moderate convergence rate $(3-4 \mathrm{~cm} / \mathrm{yr})$, Cascadia has a very warm megathrust and subducting slab. This provides opportunities for studying the effect of temperature on rock rheology, fault friction, and slab dehydration under rather extreme thermal conditions.

2) The subducting plate has ample sediment supply resulting in a deformation front but no bathymetric trench. The high sediment supply also leads to a large accretionary prism with sometimes atypical structural characteristics that vary dramatically along strike. Both creep or seismogenic motion of the shallow megathrust where it breaches the buried trench should perturb the sediment cover, giving rise to distinctive geological and geodetic signatures.

3) Partly because of the thick sediment cover, the incoming plate is one of the smoothest among all subduction zones. Moreover, because of the young age and hence small elastic thickness of the plate, the horst and graben structure formed in response to plate flexure and outer rise development is subdued. The role of sedimentation and of basement topography, both exposed and buried, in controlling fault zone structure and seismogenic behaviour is of great interest.

4) Cascadia is an archetype for the production of episodic slow slip accompanied by nonvolcanic seismic tremor (ETS) where the plate interface is at a depth of $30-40 \mathrm{~km}$. The physical mechanisms of ETS and whether slip during great earthquakes approaches, or possibly even extends into, the ETS zone is an active area of investigation.

5) At present, more than three centuries after the last great earthquake, Cascadia is currently at a late stage of interseismic deformation. After secular deformation of the upper plate is 
subtracted, Cascadia's forearc crust exhibits wholesale landward motion and a low rate of elastic margin-normal shortening, in contrast with other margins that have experienced great earthquakes more recently.

6) The level of background seismicity on the Cascadia megathrust is extraordinarily low, with seismicity on the central $550 \mathrm{~km}$ of the megathrust restricted to a few distinct patches. The recurrence of great earthquakes of $M_{w} 8-9$ against the backdrop of very low background seismicity provides an intriguing example of a characteristic earthquake sequence that deserves further research.

In the following, we review recent geodetic and seismological characteristics of the Cascadia subduction zone and discuss questions raised by those data.

\section{What is the seismogenic zone?}

\subsection{Defining the "seismogenic zone"}

The seismogenic zone of a subduction megathrust commonly refers to a depth range (or downdip distance) where the subduction interface exhibits stick-slip behaviour and is therefore thought to be capable of producing relatively large thrust earthquakes. Here we only consider the situation in which the megathrust can be reasonably approximated using a smooth contact surface. Studies of the complex internal structure of subduction faults can be found in, e.g., Bachmann et al. (2009), Kimura et al. (2012), and Rowe et al., (2013). Geometrical irregularities such as those associated with the subduction of large topographic features strongly influence the megathrust's seismogenic behaviour (Wang and Bilek, 2014; Gao and Wang, 2014; Scholl et al., 2015), and will be briefly addressed in section 7. Although the slip behaviour within the nominal seismogenic zone may vary between stick-slip and creep along strike, the concept of a seismogenic zone is useful for framing hypotheses to explain how earthquakes work (Dixon and Moore, 2007). However, different researchers sometimes use different observations and concepts to define the geographical extent of the seismogenic zone, leading to apparent conflicts between interpretations. The four most widely seen approaches to defining the seismogenic zone are summarized below. 


\subsubsection{Definition A: based on rate-state frictional properties}

According to the rate-and-state dependent friction law (Scholz, 1998; Marone, 1998), applicable to very low slip rates $(<<0.1 \mathrm{~m} / \mathrm{s})$, earthquakes can nucleate only where the composite friction parameter $(\mathrm{a}-\mathrm{b})$ is negative. Very often, this zone of potential earthquake nucleation is referred to as the seismogenic zone. For $(a-b)<0$, the frictional behaviour is referred to as velocity-weakening (i.e., the faster the fault slips, the weaker it becomes). The opposite behaviour is velocity-strengthening, which prevents rupture nucleation but may allow rupture propagation. Fig. 1 shows a widely used scenario of $(a-b)$ variation with downdip distance or depth based on interpretations of laboratory measurements of representative rock samples (Scholz, 2002; Hyndman and Wang, 1993). For real faults, it is not clear how far the rupture can propagate into the velocity-strengthening area. It depends on the degree of coseismic strengthening (Hu and Wang, 2008) and whether a high enough slip rate can be attained to allow dynamic weakening to occur (Di Toro et al., 2011; Noda and Lapusta, 2013).

\subsubsection{Definition B: based on observed rupture of large earthquakes}

This is the definition that is most closely related to seismological and geodetic observations and is the most useful for predicting ground shaking for hazard assessment. However, it can only be applied where large earthquakes have been well recorded. Moreover, because of the rate dependence of coseismic slip behaviour, as mentioned in the preceding paragraph, it is difficult to infer fault frictional properties from the observed rupture and vice versa. For great earthquakes, the rupture likely propagates beyond the velocity-weakening area (Fig. 1), and what stops the rupture may involve different processes in difference places and at different times.

\subsubsection{Definition C: based on distribution of small and medium earthquakes}

Interplate thrust events with magnitudes less than 5, and occasionally up to about 7, are often used to define the megathrust seismogenic zone in regions where there have not been instrumentally-recorded great earthquakes. Taking the Japan Trench as an example, this definition introduces a perplexing question about megathrust seismogenesis. Although smaller interplate earthquakes are known to have occurred to depths as great as $50-60 \mathrm{~km}$, rupture during the $2011 \mathrm{M}_{\mathrm{w}}=9$ Tohoku-oki earthquake was mostly above $40 \mathrm{~km}$. In fact, all the known 
$\mathrm{M}_{\mathrm{w}} \geq 9$ events worldwide appear to be limited to relatively shallow depths, even though smaller events can be deeper. Although not yet rigorously verified, it appears that smaller interplate earthquakes are distributed over a wider depth range than great earthquakes. Even in the same great earthquake, higher-frequency seismic waves appear to be radiated from the deeper part of the rupture (Lay, 2015), indicating a change in fault zone properties. Moreover, small earthquakes are often abundant on creeping segments of faults. For example, many small thrust events occur at 35 - 45 depth along the mostly aseismic plate interface at the Mariana subduction zone (Emery et al., 2011). This indicates that the extent of the "seismogenic zone" depends on the size of the earthquakes used to define it. Depending on the research objective, one may need to distinguish between zones that generate large events and those that generate small events, although defining "large" and "small" may also depend on the objective.

\subsubsection{Definition D: based on geodetically inferred interseismic locking}

This definition is widely used in subduction zones where very large earthquakes have not occurred recently but modern geodetic data are abundant (like Cascadia). Unless there are adequate near-field (including seafloor) measurements, however, it is of limited quantitative value for reasons to be discussed in section 5.1 of this paper. Because much of the locked zone is offshore while most of the so far available geodetic observations are on land, and because the inelastic behaviour of the system (especially the asthenosphere) during interseismic deformation is still poorly understood, geodetic definitions of the megathrust locked zone are severely modeldependent. To first order, if there are alternating zones along strike of locking and creeping that are large enough to be resolved, geodetically determined interseismic locking can approximately predict the along-strike distribution of patches of greatest slip in future great earthquakes, as demonstrated at the Japan Trench (Hashimoto et al., 2008; Loveless and Meade, 2010), in Costa Rica (Protti et al., 2013), and in central and northern Chile (e.g. Moreno et al., 2011; Métois et al., 2014). Inferring the distribution of slip in the dip direction from pre-event geodetic locking models, however, is more difficult. For example, all of the Japan Trench locking models published prior to the 2011 Tohoku-oki earthquake substantially over-predicted the downdip extent of locking and, by interpretation, of the future rupture zone. Because this ambiguity is relevant to Cascadia, we will discuss it in greater detail in section 5. 


\subsection{A brief history of Cascadia seismogenic zone models}

As mentioned in Introduction, there has never been an instrumentally recorded great earthquake at Cascadia, and at present there is a nearly complete absence of interplate seismicity (Tréhu et al., 2015). Models of the seismogenic zone are thus based on definitions A and D as summarized in section 2.1, with along-strike variations and recurrence behaviour based on the paleoseismic history (Goldfinger et al., 2012; Wang et al., 2013).

Hyndman and Wang (1993) used thermally-controlled frictional behaviour to define the Cascadia seismogenic zone (definition A). They proposed that the updip limit of the velocityweakening zone (Fig. 1) could be defined by a temperature of $\sim 150^{\circ} \mathrm{C}$, which marks the transition of clay minerals smectite to illite, and the downdip limit could be defined by a temperature of $\sim 350^{\circ} \mathrm{C}$, which marks the transition between velocity- weakening and strengthening in quartz-rich materials. By hand-extrapolating two-dimensional (2D) thermal model results from four margin-normal profiles, Hyndman and Wang (1995) proposed a seismogenic zone model for the entire Cascadia megathrust (Fig. 2a). They assumed that a temperature of $\sim 450^{\circ} \mathrm{C}$ could be the maximum limit of coseismic slip. At the time, it was incorrectly thought that the downdip limit of interseismic locking and the downdip limit of coseismic slip were coincident and that elastic models based on available geodetic data (leveling and tide gauge) could constrain this boundary. Other variations of this model include Flück et al. (1997) and Burgette et al. (2009).

With increased recognition of the importance of viscoelastic stress relaxation during interseismic strain accumulation, Wang et al. (2003) proposed an elastic dislocation model in which an "effective transition zone" from full locking to full slip is used to account approximately for the missing viscoelastic effects (Figure 2b). Recognizing various issues with the older geodetic data and interpretation, Wang et al. (2003) decided to use Global Positioning System (GPS) velocities and various strain rate measurements as model constraints, but they still used the temperature argument of Hyndman and Wang (1995) to define the downdip limit of full locking because of the lack of offshore data to constrain the models (see section 4.1). They also used the results of Wells and Simpson (2001) to deal with secular upper plate deformation. They assumed that coseismic slip would recover slip deficits in the locked zone but with a downdip transition extending to the middle of the interseismic effective transition zone. The resultant 
"long-narrow" coseismic rupture model, similar to that of Hyndman and Wang (1995), was used by Satake et al. (2003) and Cherniawsky et al. (2007) in their tsunami modeling.

For coseismic slip, the model of uniform rupture plus transition shown in Figs. 2a and $2 \mathrm{~b}$ is obviously unrealistic. For improved tsunami modeling, Priest et al. (2010), based on the reasoning of Wang and He (2008), assumed a bell-shaped downdip coseismic slip distribution for which a simplified version is shown in Fig. 2c. The location of the peak coseismic slip in Fig. 2c corresponds roughly to the downdip end of the locked zone in Fig. 2b. Various modified versions of this model were used to develop tsunami source scenarios for hazard assessment (Priest et al., 2010; Witter et al., 2012, 2013), some involving splay faulting.

With the rapid expansion of campaign and continuous GPS networks in the beginning of the $21^{\text {st }}$ century, contemporary GPS velocities and strain rates at Cascadia became much better defined. McCaffrey et al. $(2007,2013)$ inverted these data to determine the locking state of the megathrust and the motion of various upper plate crustal blocks. In these elastic models, some of the effects of viscoelastic relaxation may have been integrated into the elastic block motion estimates. The models of Schmalzle et al. (2014), as an update of McCaffrey et al. (2013), are shown in Figs. 2d and 2e. The two models, as well as those of McCaffrey et al. (2013), fit the data equally well, and the difference between them is due to different assumptions made to constrain the inversion. If these locking patterns are interpreted to represent slip distributions for future earthquakes, they represent seismogenic zones based on definition D. These results demonstrate the difficulty of resolving plate locking patterns from purely land-based geodetic observations.

\section{Locking or creeping?}

Based on discussions in the preceding section, it is clear that land-based geodetic observations cannot constrain the zone of interseismic locking at Cascadia, although they unambiguously indicate that the megathrust must be locked to some degree. The state of locking/creep is expected to vary along strike as well as down dip, an important issue we will address in section 7 . 


\subsection{Relevance of offshore seismicity}

To first order, land-based geodetic observations at Cascadia can be explained by either a narrow zone of full locking or a wider zone of partial locking of the megathrust, and many variations in between. Other independent information, such as background interplate seismicity, is therefore needed to help infer the state of locking. Seismicity determined from onshore networks supplemented by limited offshore ocean bottom seismometer (OBS) data indicates that at present Cascadia's plate interface is anomalously deficient in earthquake activity (Fig. 3).

North of Cape Blanco, M>3 earthquakes of any type are absent from the continental margin in catalogues dating back to 1989 , with the exception of recurrent seismicity of $\mathrm{M}<5$ events in clusters offshore central Oregon (red square in Fig. 3) and several events offshore Vancouver Island. All events off central Oregon that have been studied in detail appear to be located on or near the plate boundary and have thrust faulting mechanisms consistent with plate convergence (Tréhu et al., 2008; Williams et al., 2011; Tréhu et al., 2015). The most active cluster is thought to be associated with the interaction of a subducted seamount and the crystalline crust of the Siletz terrane in the upper plate (Tréhu et al., 2012). Preliminary analysis of OBS data acquired as part of the Cascadia Initiative (Toomey et al., 2014) from this region yields many smaller events within these clusters (Morton and Bilek, 2015). Offshore of Vancouver Island, three months of close-range monitoring in 2010 using a dense OBS network ( $20 \mathrm{~km}$ station spacing) did not yield evidence for any thrust events on the megathrust (Obana et al., 2015).

South of Cape Blanco, there is abundant seismicity, but it is difficult to determine how much is associated with slip of the megathrust and how much results from internal deformation of the subducting plate. The $1992 \mathrm{M}_{\mathrm{w}}=7.2$ Petrolia earthquake just north of the Mendocino Triple Junction $\left(\sim 40.3^{\circ} \mathrm{N}\right.$, south of the map of Fig. 3), which had a low-angle thrust mechanism (Oppenheimer et al., 1993), was either on the plate boundary or in the lower crust of the upper plate.

There are two possible explanations for the quietness of the megathrust along most of the Cascadia margin. One possibility is that the shallow megathrust is creeping as portrayed in Fig. 2e without producing detectable earthquakes except for isolated patches. At present, this is considered unlikely because purely aseismic creep of the shallow and cold part of a fault is not observed anywhere else. The creeping segment of the San Andreas Fault produces numerous 
$M<3$ earthquakes in what would be the seismogenic depth range (e.g., Shelly and Hardebeck, 2010). Creeping subduction megathrusts, such as the Mariana (Emery et al., 2011), all produce numerous small earthquakes at shallow depths (see review by Wang and Bilek, 2014). The other possibility is that the shallow megathrust at Cascadia is, for the most part, fully locked as portrayed in Figs. 2a, 2b, and 2d.

\subsection{Importance of seafloor geodesy}

Fig. 4 shows different geodetic signals predicted by a simple 2D dislocation model for a fault geometry (lower panel) appropriate for Vancouver Island or Oregon. The middle panel shows three different interseismic locking/creeping scenarios that correspond to the assumptions made in Fig. 2. The near-trench full locking scenario (red) applies to all the long, narrow, fulllocking models in Fig. 2. The partial locking scenario (blue) applies to the central Oregon part of the model in Fig. 2e. The near-trench creep scenario (green) applies to most parts of the model of Fig. 2e. The upper panel of Fig. 4 shows the resultant surface velocities relative to a fixed upper plate very far away from the trench. It is clear that land-based geodetic observations cannot tell the three locking scenarios apart, as has been demonstrated by McCaffrey et al. (2013) and Schmalzle et al. (2014), even though they predict distinctly different patterns of horizontal velocity change across the deformation front. Seafloor geodetic measurements (Gagnon et al., 2005; Bürgmann and Chadwell, 2014) of relative motion across the deformation front, however, can readily distinguish these scenarios.

Although predominant locking as portrayed by the long-narrow locking models appears to be reasonable for Cascadia, the possibility of purely aseismic creep for most or parts of the margin cannot be ruled out. Lessons from the 2004 Sumatra and 2011 Tohoku-oki earthquakes and many other recent events tell us that subduction zones have many scientific surprises in stock to challenge consensus views (Stein and Okal, 2007; Lay, 2015). For example, although Wang and Dixon (2004) questioned whether creep can be sustained near the trench while a deeper segment of the fault stays locked because of stress shadowing effects (to be further discussed in section 5.1.1), such sustained shallow creep, if observed, might result from longlasting afterslip following the previous great megathrust earthquake. Such creep could be thought of as an ongoing, long-duration slow-slip event (Meade and Loveless, 2009). Of course, 
shallow creep could also be driven by neighbouring creeping segments within the nominally "locked" zone.

It is also worth mentioning that an extreme version of the long, narrow, full-locking scenario based only on land-based geodetic observations can be found in some models for other subduction zones. For example, for most of Northern Hikurangi (Wallace et al., 2009), a narrow zone of full locking from the trench to about $5 \mathrm{~km}$ depth was modeled offshore. Slow slip events are regularly detected beneath and off the Northern Hikurangi coastline and have been interpreted to occur downdip of this extremely narrow locked zone (McCaffrey et al., 2008; Wallace and Beavan, 2010). Wang and Bilek (2014) speculated that the slow slip events may

actually extend to the trench, implying the absence of a locked zone and that repeated slow slip is a mode of megathrust creep. Recent near-trench seafloor measurements of pressure transients appear to have verified this speculation (Wallace et al., 2015).

\section{Slip behaviour of the shallowest segment of the megathrust and tsunami generation}

Tsunami hazard is a grave concern in Cascadia. The great Cascadia earthquake of AD 1700 generated a tsunami that caused substantial damage as far away as Japan (Satake et al., 2003; Atwater et al., 2005) and must have caused devastation along the local coast, as can be inferred from native legends (Ludwin et al., 2005). In assessing tsunami hazard due to future Cascadia megathrust earthquakes, the greatest challenge is in constraining tsunami sources with geologically reasonable fault geometry and coseismic slip distribution. In modeling tsunamis caused by a distant earthquake, the total moment of the earthquake is more important than rupture details. In contrast, in modeling tsunamis caused by local earthquakes, rupture details are very important, and uncertainties in source details usually overshadow uncertainties in other parameters such as rigidity distribution, bathymetry, and hydrodynamics. Fig. 5 illustrates a variety of tsunamigenic rupture scenarios that are considered geologically possible.

\subsection{Buried rupture and splay fault scenarios}

The "buried rupture" (Fig. 5a) and "splay fault" (Fig. 5b) scenarios have been used in 
Oregon for the assessment of tsunami hazard associated with Cascadia megathrust earthquakes (Priest et al., 2010; Witter et al., 2013). The buried rupture model is based on the type of shallow fault frictional behaviour represented by the $(\mathrm{a}-\mathrm{b})$ distribution in Fig. 1 (Wang and He, 2008), but it goes further by assuming that coseismic strengthening of the shallowest fault segment is large enough to prevent the rupture from breaching the trench (or deformation front). In this scenario, tsunami is generated mainly by seafloor uplift due to the elastic deformation of the upper plate. An example for this scenario is the $2005 \mathrm{M}_{\mathrm{w}}=8.7$ Nias, Sumatra, earthquake. Data from continuously monitoring GPS sites on small islands close to the trench showed that the shallowest segment of the megathrust did not rupture during the earthquake (Briggs et al., 2006) but rather slipped slowly afterwards (Hsu et al., 2006), indicating a highly velocity-strengthening behaviour. Another example is the $2010 \mathrm{M}_{\mathrm{w}}=8.8$ Maule, Chile, earthquake. Its rupture did not breach the trench in most models (with the notable exception of Yue et al., 2015, which locally includes local slip-to-the-trench immediately up-dip from the patch of greatest slip).

Activation of a splay fault (Fig. 5b) can be a more extreme consequence of the coseismic strengthening of the shallowest megathrust segment (Wang and $\mathrm{Hu}, 2006$ ). This scenario has been speculated for the $1946 \mathrm{M}_{\mathrm{w}}=8.2$ earthquake at the Nankai, Japan, subduction zone (Baba et al., 2005) and proposed for a number of other subduction earthquakes (Fukao, 1979), including the great "Good Friday" earthquake off Alaska in 1964 (Plafker, 1972). Although the presence of a splay fault has not been decisively confirmed in Cascadia, there is indirect structural evidence for its possible presence along parts of the margin at the boundary between the Pleistocene and Holocene accretionary wedge materials (Priest et al., 2010).

\subsection{Trench-breaching rupture}

Bathymetry and seismic survey observations convincingly indicate that large trenchbreaching rupture occurred during the 2011 Tohoku-oki earthquake (Fujiwara et al., 2011; Kodaira et al., 2012). This has raised a new issue for tsunami hazard assessment at Cascadia and many other margins. The seaward motion of the sloping seafloor as a result of large slip at the trench (Fig. 5c) is generally considered to be responsible for the devastating tsunami following this earthquake. The large trench-breaching slip came as a surprise to many researchers because the shallowest segment of the megathrust is usually thought to exhibit velocity-strengthening 
(Fig. 1) (Wang and $\mathrm{Hu}, 2006$ ). While one can question whether the shallowest segment at Japan Trench is velocity-strengthening (i.e. whether the $(\mathrm{a}-\mathrm{b})<0$ part of the curve in Fig. 1 should start from the trench), coseismic slip of a velocity-strengthening segment may occur for three reasons. (1) The degree of coseismic strengthening may be too low to fully stop the rupture (Hu and Wang, 2008). (2) A fault segment that exhibits velocity-strengthening at very low slip rates may undergo dramatic weakening if driven to slip at seismic slip rates ( $1 \mathrm{~m} / \mathrm{s}$ ) (Di Toro et al., 2011; Faulkner et al., 2011; Noda and Lapusta, 2013). (3) Dynamic effects of seismic wave interaction in the wedge-shaped hanging wall may facilitate rupture propagation (Kozdon and Dunham, 2013).

Although trench-breaching rupture can be explained, it is not universal, as demonstrated by the "buried rupture" examples discussed in the preceding section. Globally, an important question is whether trench-breaching rupture is common or rare. Seafloor geodetic monitoring, laboratory studies of materials of the shallowest part of the megathrust fault, and structural analysis constrained by seismic imaging are needed to address this question.

Regarding the potential for a large trench-breaching rupture at Cascadia, we expect that clues will come from analysis of geological structures both seaward and landward of the deformation front. In contrast to the Japan Trench, Cascadia has thick sediment $(2.5-4 \mathrm{~km})$ on the incoming plate and a filled trench, and the young accretionary wedge is wide (Fig. 6). If trench-breaching ruptures frequently occurred during previous megathrust earthquakes, they should have left a signature in the sediment cover, although to date there is no widely accepted model for what this signature should be (Hubbard et al., 2015).

The seismically-imaged structure of the Cascadia deformation front varies considerably along strike (Fig. 6). The margin offshore Vancouver Island and central Oregon (Figs. 6b and 6d) is generally characterised by a seaward-verging thrust fault at the deformation front, with backthrusts on the landward side of the frontal fold (e.g. Hyndman et al., 1994; MacKay, 1995; Fisher et al., 2006). Off southern Oregon, the structural signature of the deformation front is characterized by large landslides (Goldfinger et al., 2000). In contrast, the young accretionary wedge off northern Oregon and Washington, as can be seen in Figs. 6a and 6c, is wider and characterized by folds and faults that are often landward-vergent (e.g. Flueh et al., 1998; BoothRea et al., 2007). This segment of the margin was recently imaged with a densely spaced set of seismic reflection profiles by the open-access COAST project (Holbrook et al., 2012). In both 
the mixed/landward vergent and seaward vergent regimes, small-offset "proto-faults" that are both landward and seaward vergent are observed seaward of the deformation front (MacKay, 1995; Booth-Rea et al., 2007). It is beyond the scope of this paper to review the structural analysis of these data, but ongoing and future work should provide new insights into whether the observed structures near the deformation front indicate that trench-breaching earthquakes have occurred.

\subsection{Tsunami earthquakes}

Not discussed here, and not shown in Fig. 5, is the scenario of standalone rupture of the shallowest segment. This type of shallow slip is commonly agreed to be a mechanism for tsunami earthquakes - events that generate large tsunamis without causing correspondingly strong ground shaking. The mismatch between the large tsunami and the relatively weak shaking is attributed to slip on the fault that is slower than a "normal" earthquake but still much faster than geodetically slow slip. A recent example is the $2010 \mathrm{M}_{\mathrm{w}}=7.8$, Mentawai earthquake (Newman et al., 2011; Hill, 2012). Hill et al. (2012) propose that coseismic slip in this event occurred along the shallow megathrust without involving secondary faulting, and that the updip tapering of the slip caused gentle buckling of the overlying sediment formation, resulting in a large tsunami. This would therefore be a more compact and locally more intense version of the buried rupture model of Fig. 5a. The most intriguing aspect of the Mentawai event is that the shallow segment that slipped in 2010 did not slip during a $\mathrm{M}_{\mathrm{w}}=8.4$ earthquake in 2007 that ruptured the megathrust directly downdip of the 2010 rupture zone. Tsunami earthquakes are rare but dangerous events; whether parts of the Cascadia megathrust may exhibit this behaviour deserves some contemplation.

\section{Downdip limit of the seismogenic zone}

Many different observations have been proposed to define the downdip limit of the seismogenic zone (DLSZ) (see review for Cascadia by Hyndman, 2013). Because each type of evidence pertains to a specific definition of the seismogenic zone (section 2.1), inter- 
comparisons are problematic. In some cases, the proposed relationship between an observation and its interpretation as a proxy for the downdip limit of the DLSZ is highly speculative (such as the occurrence of a broad band of seismic reflectivity in the lower crust). Some observations may intrinsically lack the necessary resolution. For example, although geological evidence for coseismic coastal subsidence in past earthquakes can tell us that the responsible megathrust rupture must have been mostly offshore, it cannot constrain the rupture's downdip limit because of inadequate data coverage in the margin-normal direction (Wang et al., 2013). In this section, we first revisit the downdip limit of interseismic locking based on geodetic observations, which globally are the most widely used type of data. We then briefly discuss new insights about the thermally defined DLSZ, which is frequently used for Cascadia.

\subsection{Geodetic interseismic deformation cannot constrain the downdip limit}

Although GPS observations convincingly show that the Cascadia megathrust is currently locked to some degree and that the zone of locking is mostly offshore, they cannot constrain the DLSZ or the future rupture zone for reasons discussed below.

\subsubsection{Stress shadow}

The state of no slip, or "apparent locking", can arise for different reasons. If the shear stress along the fault is less than the strength of the fault, the fault cannot move; this is the true state of locking. However, a weak patch of the fault that has reached its failure stress may be kept from slipping simply because a neighbouring stronger patch is truly locked (Wang, 2007). This phenomenon is referred to as "stress shadowing". Because of stress shadowing, the geodetically constrained zone of apparent locking tends to be larger than the zone of true locking. The influence area of a stress shadow depends on the history of fault slip and other regional conditions and can impact both the apparent updip and downdip limits of the locked zone (Hetland and Simons, 2010).

\subsubsection{Temporal changes in locking width}

The zone of true locking may change with time during the interseismic period. In the 2D model of Liu (2013), tuned for Cascadia, the downdip limit of the fully locked zone changes by 
about $30 \mathrm{~km}$ over the interseismic period, from some distance downdip of the frictional stability transition $(\mathrm{a}-\mathrm{b}=0)$ to some distance updip of it (Fig. 1). Narrowing of the locked zone in this fashion is seen also in the strike-slip fault model of Shimamoto and Noda (2014) and appears to be a common feature of rate-state friction models that invoke the type of $(a-b)$ distribution represented by the solid line in Fig. 1. This model-predicted temporal variation of the locking width further complicates the relationship between the geodetically constrained locked zone and the future rupture zone.

\subsubsection{Viscoelastic effects and "interseismic" stress relaxation}

Interseismic locking is commonly modeled using the "back-slip" method (Savage, 1983). With the component of steady subduction subtracted, the fully locked zone becomes a zone that slips backward at the subduction rate like a creeping normal fault, and any zone of full-speed creep becomes a zone of zero back slip. A main problem in the vast majority of such models is the neglect of the effect of viscoelastic stress relaxation (Wang et al., 2012a). In the viscoelastic Earth, stress accumulation due to the locking of the subduction fault is being viscoelastically relaxed at the same time, such that the mantle offers less resistance to deformation than in an elastic Earth (Hu et al., 2004; Pollitz et al., 2010; Li et al., 2015). As a result, the locking of the fault causes deformation farther away from the plate boundary. We call this process "interseismic stress relaxation" because the stress being relaxed is induced by ongoing fault locking. It should not be confused with post-seismic stress relaxation, which relaxes the incremental stress induced by the preceding earthquake. Interseismic stress relaxation takes place as long as the fault is locked, regardless of how long it has been since the previous earthquake and whether the deformation is steady or changing with time.

In an elastic model, however, the mantle stays elastic and offers greater resistance to deformation. Two approaches are commonly seen in the literature on inverting interseismic geodetic observations using elastic back-slip models. In one approach, the fault used in the inversion extends to a much greater depth than a seismogenic zone based on any of the definitions in section 2.1 (and Fig. 1). To explain the broad zone of observed interseismic deformation, the effect of mantle relaxation is transferred to the deeper fault, resulting in an overestimate of the downdip extent of the locked or partially locked zone in the model. For example, in a model of this type prior to the 2011 Tohoko-oki earthquake, significant fault 
locking was inferred to have occurred as deep as $100 \mathrm{~km}$ (Suwa et al., 2006). However, an artificially wide locked zone can intentionally be used to approximate the effect of interseismic stress relaxation in an elastic model (Wang et al., 2003) (Fig. 2b). In the other approach, the locked zone is limited to a depth of $30-50 \mathrm{~km}$, which is considered reasonable based on other geophysical considerations. Because the back-slip on this narrower zone cannot cause sufficient deformation at large distances, some of the observed far-field interseismic deformation is either left unaccounted for or explained as long-term geological deformation (to be further discussed in the next section). Also, in order to fit near-field observations, inversion algorithms often use large back-slip rates on parts of the locked zone to overcome the resistance to deformation offered by the elastic model. In many publications, the large rates exceed the subduction rate, giving rise to the physically unreasonable scenario of normal-faulting creep of the megathrust.

\subsubsection{Upper plate deformation and block models}

In some cases, such as in the central Andes, elastic dislocation models cannot explain interseismic deformation away from the plate boundary even when a very wide locked zone is allowed, and the unexplained portion is interpreted to indicate long-term secular motion of crustal blocks of the upper plate (Chlieh et al., 2011) (the second approach discussed in section 5.1.3). Li et al. (2015) have shown that this apparent block motion may actually result from interseismic viscoelastic stress relaxation.

In central and southern Cascadia, there is prominent clockwise rotation of a large portion of the upper plate that needs to be accounted for in modeling interseismic deformation (McCaffrey et al., 2007, 2013). An example of a possible uncertainty induced by the introduction of blocks can be found in northern Cascadia, where there is little independent evidence for fast secular deformation of the upper plate. Here, McCaffrey et al. (2007, 2013) had to introduce 2-3 mm/yr of convergence across a NW-trending block boundary $\sim 300 \mathrm{~km}$ from the deformation front in order to explain observed margin-normal shortening extending to this area. Using a viscoelastic mantle rheology, Wang et al. (2012b) explained the same long-range deformation in northern Cascadia as the effect of interseismic viscoelastic relaxation. For central and southern Cascadia, neglecting interseismic stress relaxation could lead to an underestimate of the long-term extension of the broad back arc area (Basin and Range).

To separate estimates of megathrust locking from block motion, independent observations of 
block boundaries and kinematics are needed. Although the block motion models of McCaffrey et al. (2013) and Wells and Simpson (2001) are useful working models for upper plate deformation, one should be mindful of the associated uncertainties. The megathrust locking model shown in Fig. 2b used the block motion model of Wells and Simpson (2001), and those in Figs. 2d and 2e used the McCaffrey et al. (2013) block motion model, and both contain uncertainties for this reason.

\subsubsection{Interseismic vertical deformation}

Including land-based vertical interseismic deformation data does not improve resolution of megathrust locking at Cascadia; the drastically different models in Figs. 2e and 2d both included this type of data as constraints. Nevertheless, elastic dislocation models often lead to an impression that the vertical data can better constrain the downdip limit of locking. As shown by the elastic models in Fig. 4, in comparison to the horizontal component of surface motion, the vertical component is indeed more sensitive to the location and sharpness of the downdip termination of megathrust locking. However, although the models in Fig. 4 correctly demonstrate the importance of having seafloor geodetic observations, especially for resolving the updip extent of locking, they do not illustrate one of the most diagnostic aspects of interseismic deformation - its evolution with time. The best vertical data set that covers a full earthquake cycle are the leveling data from the Nankai subduction zone, southwest Japan (Thatcher, 1984), some of which were compared with Cascadia leveling data in previous studies (Hyndman et al., 1995; Hyndman and Wang, 1995). It is illuminating to re-examine what these data can tell us about interseismic deformation.

Uplift rates from Nankai leveling data along two margin-normal profiles nearest to the rupture zone of the $1946 \mathrm{M}_{\mathrm{w}}=8.2$ megathrust earthquake are reproduced in Fig. 7. Both lines start at the coast and extend landward. The measurements over a timespan of about three to four decades before the 1946 earthquake (red) represent late-stage interseismic deformation. To accentuate the long-wavelength characteristics of these measurements, we have hand-smoothed the data originally presented by Thatcher (1984). Leveling only measures relative elevation changes (or tilts). The data are sometimes tied to tide gauges so that sea level is used as a common reference. Because tide gauge data introduce other errors and because we are interested only in the overall shape of the elevation profiles, we make no effort to tie the measurements to a 
common reference. Every profile in Fig. 7 is thus subject to an arbitrary vertical shift.

The most striking feature of these Nankai observations is their change with time, consistent with the prediction of viscoelastic models (Thatcher and Rundle, 1984). By comparing the midcycle profile (blue) to the coseismic profile (gray) and assuming elastic behaviour, Hyndman and Wang (1995) incorrectly inferred that interseismic and coseismic deformation were mirror images of each other. With global observations, we now understand that interseismic deformation changes with time because of viscoelastic relaxation of the mantle (Wang et al., 2012a; Sun et al., 2014).

The second striking feature is that the uplift rate profile at the late stage of interseismic deformation is rather flat. Compared to Nankai, paleoseismic data indicate that Cascadia megathrust ruptures were located farther offshore (Leonard et al., 2010; Wang et al., 2013), so that the largest coseismic subsidence occurred at the coast or on the continental shelf (Fig. 7). If the late-stage Nankai observations (Fig. 7, red lines) are applicable to Cascadia, the coastal area is not necessarily tilting landward (Fig. 7a) as predicted by many elastic models (Fig. 4). Sea level observations indicate landward tilting of Vancouver Island over the past few thousand years (Hutchinson, 2000), which cannot be explained using interseismic deformation. If this signal is subtracted from previous published leveling data (Wang et al., 2003), the remaining flat profile is reminiscent of the Nankai leveling observations. Reported leveling data for the Cascadia margin generally show landward tilt (e.g., Burgette et al., 2009). Whether they reflect longer-term tilt like Vancouver Island is yet to be investigated.

In general, the value of vertical interseismic deformation observations has not been adequately explored. One reason is the poor signal-to-noise ratio. In interseismic GPS velocities, the vertical component is much smaller than the horizontal component (Fig. 4) yet the uncertainties are well known to be much larger. Various meteorological and hydrological processes give rise to vertical deformation signals of timescales of years to decades, and removing these "noises" for the purpose of isolating interseismic deformation signals remains a challenge. Another reason is that at subduction zones the geological and geodynamic processes responsible for crustal tilting, detected by vertical measurements, are more poorly understood than those responsible for crustal straining, detected by horizontal measurements. For example, what causes the millennium-timescale landward tilting of Vancouver Island mentioned above is presently unknown. 


\subsection{New questions about the thermal limit and fault gouge rheology}

There is no question that thermally-regulated rheology provides the ultimate control on the downdip termination of seismic behaviour of subduction megathrusts, although the exact temperature may depend on a number of other parameters. Assuming a downdip distribution of friction parameter $(\mathrm{a}-\mathrm{b})$ as represented by the solid line in Fig. 1, Hyndman and Wang (1993) proposed to define the seismogenic zone using the deeper stability transition (definition $\mathrm{A}$ in section 2.1). Laboratory friction experiments on granitic rocks showed that the transition happens at temperatures around $350^{\circ} \mathrm{C}$ (Blanpied et al., 1991). Crustal earthquakes appear to be limited by a similar temperature (Wong and Chapman, 1990). Hyndman and Wang (1993) thus used this temperature to define the stability transition. They also assumed that the actual seismic rupture could extend into the velocity-strengthening zone of $(a-b)>0$ but was limited by, for lack of more precise knowledge, a temperature of $450^{\circ} \mathrm{C}$. Here we discuss two new issues prompted by recent publications.

\subsubsection{The role of gabbro}

He et al. (2007) reported over 30 friction experiments on gabbro gouge under hydrothermal conditions for various combinations of normal stress, pore fluid pressure, and temperature. For the majority of the experiments, the gouge exhibited velocity-strengthening for the tested temperatures up to $600^{\circ} \mathrm{C}$, with a few experiments showing velocity-weakening in the $200-$ $300^{\circ} \mathrm{C}$ range. Two experiments at $416^{\circ} \mathrm{C}$ and one at $507^{\circ} \mathrm{C}$, at effective pressure $100 \mathrm{MPa}$, exhibited velocity-weakening. These two data points were used by Liu and Rice (2009) to argue for seismogenic behaviour of gabbro up to a temperature of $510^{\circ} \mathrm{C}$ in rate-state friction modelling of Cascadia slow slip events. In contrast, Michell et al. (2015) more recently reported

friction experiment results for gabbro that show velocity-weakening for temperatures higher than $100^{\circ} \mathrm{C}$ and up to $600^{\circ} \mathrm{C}$, the highest temperature tested in their experiments, for a variety of laboratory conditions. Because the igneous oceanic crust is mafic and the subducting slab may be in contact with the gabbroic lower crust of the upper plate Crescent/Siletz terrane (Tréhu et al., 1994), the frictional behaviour of gabbro gouge may be relevant for the Cascadia megathrust. If earthquakes could initiate here at temperatures as high as $510-600^{\circ} \mathrm{C}$, the downdip limit of the 
seismogenic zone (definition A) would be much deeper than generally thought.

A key question, however, is whether gabbro represents megathrust fault gouge. Because the surface of the basaltic oceanic crust always has relief, it always carries some sediment as it subducts, and in some cases several hundred meters of sediment may be subducted, as suggested by Figs. $6 \mathrm{~b}$ and $6 \mathrm{~d}$. At greater depths, pieces of the underside of the upper plate and/or the top of the oceanic crust may be entrained in the subduction process. The fault zone therefore consists of a melange of rocks from various sources (Kimura et al., 2012), with bands of more localized shear (Rowe et al., 2013). Seafloor sediments, especially terrigenous sediment that is abundant at Cascadia, are rich in quartz, and these entrained sediments strongly affect megathrust behaviour. He et al. (2013) conducted further experiments on the primary ingredients of gabbro, plagioclase and pyroxene. They found that although plagioclase and pyroxene gouge tend to exhibit velocityweakening over a wide temperature range, the addition of a small amount of quartz can make the gouge highly velocity-strengthening. The appropriate gouge composition for Cascadia, and how it changes along strike and dip, deserves further research.

\subsubsection{Hydrothermal cooling of the subducting crust}

Recently, effects of vigorous hydrothermal circulation in the subducted oceanic crust have been incorporated into models of the shallow thermal regime of subduction zones. It is well known that fractured basaltic crust of young oceanic lithosphere hosts buoyancy-driven hydrothermal convection (see Sclater (2004) for a historical account), and that convection can still be vigorous even under a nearly impermeable sediment cover (Davis et al., 1997). It is logical to envision that the circulation may be sustained even after subduction if there is high enough permeability and large enough thermal buoyancy. Spinelli and Wang (2008) showed that heat flow measurements in one area of the Nankai subduction zone cannot be explained unless very vigorous hydrothermal circulation is assumed to occur in the subducted crust. The same concept has been applied to other subduction zones (e.g., Rotman and Spinelli, 2014; Wang et al., 2015), including Cascadia (Cozzens and Spinelli, 2012). In these models, the fluid circulation itself is not simulated, but the thermal effect of the circulation is parameterized by using a very high thermal conductivity value representing high Nusselt number following the recipe of Davis et al. (1997). 
The effect of the circulation is to "move" heat from the deeper part of the system to the trench, resulting in a warmer trench but colder megathrust at greater depths. In the results of Cozzens and Spinelli (2012), the location of the $350^{\circ} \mathrm{C}$ isotherm of the Cascadia megathrust is moved landward by $30-55 \mathrm{~km}$ from what was shown in Hyndman and Wang (1995). Hyndman (2013) questions the necessity of introducing this vigorous circulation at Cascadia. Indeed, the same heat flow data off and on Vancouver Island have been examined in several thermal modeling studies (Wang et al., 1995; Currie et al., 2004; Wada et al., 2008; Gao and Wang, 2014), and can be explained without including circulation. Therefore, how the circulation affects megathrust temperature at Cascadia is still an open question.

\section{Controversial relationship between the seismogenic zone and ETS}

Since the discovery of episodic slow slip events (SSEs) in Cascadia (Dragert et al., 2001) and non-volcanic seismic tremor that accompanies these geodetically-detected events (Obara, 2002; Rogers and Dragert, 2003), ETS and a variety of related phenomena have been the focus of intense study in Cascadia and around the world. Here we will not attempt a comprehensive review of the many studies characterizing the time/space patterns of ETS but will focus on a few issues related to understanding the seismogenic behaviour of the megathrust. See Schwartz and Rokosy (2007) or Peng and Gomberg (2010) for global reviews and Gomberg et al. (2010) and Boyarko et al. (2015) for reviews focusing on Cascadia.

Cascadia SSEs are centered at a depth of about $30-40 \mathrm{~km}$ if modelled using the plate interface geometry of McCrory et al. (2004, 2012) (Dragert and Wang, 2011). In map view, the tremor distribution presented in most publications is shifted slightly landward of the corresponding SSEs (e.g., Dragert and Wang, 2011; Wech and Creager, 2011; Boyarko et al., 2015). Determining tremor depth is difficult and depends on the method used (Kao et al., 2005). Small low-frequency earthquakes (LFEs) embedded in the tremor cloud are interpreted to be particularly energetic tremor sources and are representative of tremor sources more generally (Shelly et al., 2007). Based on this interpretation, LFEs identified and located by Bostock et al. (2012) and Royer and Bostock (2014) best define the tremor location in northern Cascadia. These LFEs form a rather thin band, consistent with the interpretation that LFEs and tremor 
originate mostly along, and are driven by slip or shear of, the fault zone. The same understanding applies to the LFE/tremor distribution in the Nankai subduction zone (Obara, 2010) and along the San Andreas Fault (Shelly and Hardebeck, 2010). When tremor occurs without a geodetic signal; it is probably because the responsible slip is too small to be detected with commonly used geodetic methods (e.g., Wang et al., 2008; Obara, 2011; Dragert and Wang, 2011). In this situation, tremor is considered indicators of slip.

\subsection{Does updip limit of ETS correspond to downdip limit of seismogenic zone?}

A question of paramount importance to both subduction zone geodynamics and earthquake risk mitigation is whether ETS marks the downdip limit of the seismogenic zone (Chapman and Melbourne, 2009). Based on rate-state modeling, SSEs can be manifestations of oscillatory behaviour of the fault within the velocity weakening zone $(a-b<0)$ but very near the stability transition of $(a-b)=0$ (see Fig. 1, red solid line) under extremely low effective normal stresses (e.g., Liu and Rice, 2009). Thus, using seismogenic zone definition A (Fig. 1), the modeled SSEs should be within the seismogenic zone but near its downdip limit. If the actual rupture in great earthquakes extends deeper than the stability transition (B in Fig. 1), the model SSEs may fall well within the rupture zone. Regardless of rate-state models, however, it is often assumed that the ETS zone should be located outside and immediately downdip of the seismogenic zone. Observations shown in Fig. 8 illustrate that the spatial relationship between the ETS zone and seismogenic zone is more complex.

At Nankai (Fig. 8b), tremor occurs episodically together with what is known as "short-term" SSEs of durations of days to a few weeks, identical to the phenomena of ETS at Cascadia. Between the downdip limit of the rupture zone of the 1944/1946 great megathrust earthquakes and the ETS zone, there is a gap that is from time to time filled by "long-term" SSEs that last several months to several years each time (Fig. 8b). Note that for this comparison in Nankai, the 1944/46 rupture zone must be based on coseismic observations. Geodetic inversion results of Sagiya and Thatcher (1999), cited in many ETS publications to extend the rupture zone to the ETS zone, included postseismic deformation during the decade after the earthquakes and substantially overestimated the downdip extent of the actual coseismic rupture. Along the San Andreas Fault, the creeping segment northwest of Parkfield produces numerous small 
earthquakes. This seismicity band and the rupture zone of the 2004 Parkfield earthquake roughly delineate a zone of seismogenic behaviour. Between this "seismogenic zone" and the tremor zone, there is a gap (Fig. 8c). It is possible that a similar gap between the downdip limit of slip in great earthquakes and the updip limit of ETS activity is present in Cascadia (Fig. 8a), although the gap-filling long-term SSEs seen in Nankai (Fig. 8b) have not been detected in Cascadia.

The observations at Nankai and San Andreas Fault are not necessarily in conflict with the notion of ETS being a manifestation of oscillatory slip behaviour near the frictional stability transition. Instead, these observations may indicate that the rate-state models or their applications need to be modified. For example, by introducing strong dilatancy of the fault zone during a megathrust earthquake, Liu (2013) showed that the rupture could stop short of reaching the ETS zone near the stability transition. Alternatively, as discussed in the following section, these observations may indicate that the simple downdip variations in $(\mathrm{a}-\mathrm{b})$ represented by the solid line in Fig. 1 should be questioned and more complex models (for example, dashed line in Fig. 1) should be considered.

\subsection{ETS and the mantle wedge corner}

We consider what geologic processes could result in the dashed line in Fig. 1. Wada et al. (2008) speculated that the serpentinized mantle wedge corner may play an important role, with ETS facilitated by the presence of high fluid pressure and hydrous minerals, consistent with the fact that ETS in both Nankai and Cascadia occurs where the plate boundary is thought to be at depths of $30-40 \mathrm{~km}$. Following the same logic, Kirby et al. (2014) speculated that the San Andreas tremor may be related to a relic, but still actively dehydrating, mantle wedge that was serpentinized when the present San Andreas boundary was a subduction zone. Depth variations of the San Andreas tremor (Fig. 8c) may reflect upward displacement of buoyant serpentinite blocks in various places (Kirby et al., 2014). Hyndman et al. (2015) proposed that an expected enrichment of silica just above the wedge corner might be responsible for the ETS, implying that the tremor source might not be on the plate interface. Gao et al. (2015) proposed that the gap observed at Nankai (and possibly also at Cascadia) is the result of multiple thermo-petrologically controlled transitions between frictional and viscous behaviour of the fault zone, with a shallow

frictional regime responsible for megathrust earthquakes and a deeper frictional regime related to 
the mantle wedge corner responsible for ETS. In terms of $(a-b)$, the downdip variation proposed by Gao et al. (2015) is approximately represented by the red-dashed line in Fig. 1.

The spatial relationship between ETS and the mantle wedge corner, however, is controversial. The Japanese research community (e.g., Kato et al., 2010; Obara, 2011), generally considers that the Nankai ETS occurs mostly landward of the wedge tip, with long-term SSEs occurring between the ETS zone and the seismogenic zone (Fig. 9a). In contrast, many North American researchers (e.g., Audet et al., 2009; Peng and Gomberg, 2010) have presented models in which ETS is entirely seaward of the mantle wedge tip and directly adjacent to the downdip edge of the seismogenic zone (Fig. 9b).

The controversy arises partially from the difficulty in determining the position of the upper plate Moho beneath the forearc crust. For Nankai, the forearc Moho is imaged in some places (e.g., Kato et al., 2010). In Cascadia, the general lack of a strong impedance contrast between the lower crust and mantle wedge is attributed to the high seismic velocity of the lower Siletz terrane crust and extensive hydration of the mantle wedge (Brocher et al., 2003). These are such that the velocity of the uppermost mantle may actually be lower than the velocity in the lower crust (Bostock et al., 2002). Extrapolating the Moho trenchward from where it is imaged at 30-35 km depth beneath the eastern edge of the forearc, as attempted by McCrory et al. (2014), requires assumptions about Moho geometry.

There are ample observations (e.g. Audet and Kim, 2016) and theoretical arguments to support the notion that ETS is related to very high pore fluid pressure and hence very low effective normal stress on the fault (e.g., Shelly et al., 2006; Liu and Rice, 2009). Wada et al. (2008) argued that the mantle wedge corner provides an environment conducive to high pore fluid pressure. Wang and Gao (2016) further reasoned that serpentine saturation of the tip portion of the mantle wedge and silica deposition in the lower continental crust updip of the wedge tip will both reduce permeability, such that very high pore fluid pressure can develop both updip and downdip of the mantle wedge corner. This zone of high pore fluid pressure may give rise to a second zone of $(\mathrm{a}-\mathrm{b})<0$ responsible for ETS, as shown by the red-dashed line in Fig. 1. If so, the ETS is expected to extent both seaward and landward of the mantle wedge tip (Fig. 9c). Geological and geophysical constraints on the relationship of the ETS zone to the mantle wedge corner hold the key to understanding its relationship with the seismogenic zone. 


\section{Along-strike variations of slip behaviour}

Like all subduction zones, the slip behaviour of the Cascadia megathrust must vary along strike. To explain along-strike variations in coastal subsidence during the AD 1700 Cascadia earthquake estimated from microfossil studies (Hawkes et al., 2011; Engelhart et al., 2013), the most recent rupture model for this event invokes patches of high slip separated by areas of low slip (Wang et al., 2013), as reproduced in Fig. 10. Also shown in Fig. 10 are segmentation boundaries of ETS activities defined by changes in periodicity and/or common endpoints of ETS events (Brudzinski and Allen, 2007). These boundaries also correspond approximately to the distribution of forearc basins as mapped by seismic reflection data or inferred from gravity anomalies (Wells et al., 2003) and to the along-strike lengths of past Cascadia megathrust ruptures estimated by Goldfinger et al. (2012) from 10,000 years of turbidity deposits. That these four different types of observations show similar segmentation implies that some of the variability in along-strike rupture behaviour are persistent and are therefore likely geologically controlled. For hazard assessment, it is important to know whether along-strike variations in earthquake histories reflect only natural randomness in fault slip behaviour or are controlled by geological processes.

As discussed in Section 3, small earthquakes may indicate the current locking state of the megathrust. In spite of the general lack of plate interface seismicity, patchy seismicity of $2>M>5$ has been detected on the plate interface offshore of central Oregon in the past decade at the rate of $\sim 6$ events/year (Tréhu et al., 2015) (Fig. 3). This activity is interpreted to be related to interactions between subducting seamounts and the volcanic basement of the upper plate, which swings seaward in this region (Wells et al., 1998; Tréhu et al., 2012). The location of this activity is similar to one of the segmentation boundaries inferred from the microfossil, turbidity, and ETS observations (Fig. 10) and is consistent with the notion that subducting seamounts cause megathrust creep that produces small to medium-size earthquakes (Wang and Bilek, 2011, 2014). This area is therefore a strong candidate for geologically controlled, persistent resistance to large coseismic slip. This patch of the fault may arrest slip in some earthquakes but slide in others, depending on how hard it is driven to slip by its neighbouring segments to the north and/or south. The coseismic slip behaviour of the neighbouring segments is in turn related to their own slip 
history.

Based on the geodetic inversion models shown in Fig. 2d and 2e, Schmalzle et al. (2014) propose that the segment between $43.5^{\circ} \mathrm{N}$ and $46^{\circ} \mathrm{N}$ shows a different interseismic behaviour. As discussed in sections 2.2 and 3, currently available geodetic data have very limited resolving power offshore, and details of the models derived from these data are strongly influenced by model assumptions. Only future seafloor geodetic measurements will help clarify the locking pattern. None-the-less, along strike variability in slip behaviour is indicated by multiple data sets (Fig. 10) and is an important subject of future research.

\section{Summary}

Using the Cascadia subduction zone as an example, we have reviewed a few outstanding issues in the study of great subduction earthquakes. These issues are unresolved because presently available observations do not offer adequate constraints. Consequently, working hypotheses are controversial. Our main points can be summarized as follows.

(1) Four different definitions of the seismogenic zone of subduction megathrusts are used, and sometimes conflated, by the research community. As explained in section 2.1, the four definitions are based on: (A) the predicted stability transition of rate-and-state dependent friction; (B) the observed rupture zone of large interplate earthquakes; (C) the observed distribution of small and medium earthquakes; and (D) the geodetically inferred zone of interseismic fault locking. At Cascadia, and other subduction zones where large subduction earthquakes have not been instrumentally recorded, definition D is commonly used. The four definitions are based on different geophysical processes, and it is important for researchers to be aware of these differences and to specify the observations being used to define the seismogenic zone.

(2) Land-based geodetic observations unambiguously indicate that the Cascadia megathrust is presently locked to some degree, but for any given location along the margin these observations cannot resolve whether the megathrust is fully locked or creeping at a very slow rate. Near absence of detectable interplate seismicity is currently assumed to 
indicate full locking along most of the Cascadia margin. Although this assumption is logical, reliably defining the true state of locking requires seafloor geodetic observations near the deformation front. For hazard assessment and geodynamic research at Cascadia, seafloor geodesy is an urgent next step.

(3) The slip behaviour of the shallowest segment of the megathrust, especially its ability to slip coseismically and generate tsunamis, is poorly known because of the paucity of nearfield observations. Large trench-breaching rupture during the 2011 Tohoku-oki earthquake requires researchers to take a fresh look at the shallow megathrust at Cascadia and many other subduction zones. Although structural observations have not yet been conclusively correlated with diagnostic signs of previous large trench-breaching slip, this is an area where ongoing and future research may be fruitful. Comparative studies with other subduction zones that have recently experienced great earthquakes are critical.

(4) Interseismic geodetic observations cannot constrain the perimeter of each truly locked fault patch because of the effect of stress shadowing. More importantly, because of interseismic (as opposed to postseismic) viscoelastic stress relaxation, interseismic deformation is not a subdued mirror image of coseismic deformation, and the downdip limit of the locked zone generally cannot be determined from geodetic data alone. In models that neglect interseismic stress relaxation, long-wavelength along-strike variations in the state of locking may be resolved, but variations in the dip direction are unreliable. In these models, part of the observed interseismic deformation away from the plate boundary due to interseismic stress relaxation has likely been incorrectly attributed to either fault locking to very large depths or long-term deformation of the upper plate. Future research efforts should use viscoelastic rather than purely elastic models to determine the degree of locking and its along-strike variations.

(5) The spatial relation between the megathrust seismogenic zone and the ETS zone is controversial. In rate-state friction models, slow slip events can be a manifestation of oscillatory slip behaviour of the velocity-weakening zone near the stability transition. An observed spatial gap between earthquake rupture and the tremor zone at the Nankai subduction zone and along the San Andreas Fault indicates that ETS may not define the limit of the seismogenic zone. Determining the presence or absence of this gap in Cascadia is important. The assumption of monotonic increase of velocity-strengthening 
behaviour with depth downdip of the velocity-weakening zone (Fig. 1, solid line) needs to be re-evaluated. Studying the relation of the ETS zone with the mantle wedge corner is important to understanding its relation with the seismogenic zone.

(6) The Cascadia megathrust exhibits along-strike variations in its slip behaviour. The present state of interseismic locking may also vary along strike but is difficult to resolve using only land-based geodetic observations because the signal is very small compared to uncertainties in the data. Along-strike variations in the occurrence of interplate seismicity may contain information on the state of locking vs. creep. At Cascadia, a possible candidate for creep is beneath the continental shelf off central Oregon, where interaction between a subducting seamount and the crystalline crust of the upper plate may be responsible for small earthquakes on and near the megathrust. In future research, it is important to investigate whether there are structurally controlled, persistent barriers to large coseismic slip, as well as other factors that may give rise to heterogeneity in slip behaviour such as pore fluid pressure and fault gouge composition.

\section{Acknowledgements}

The authors thank the Editorial team of Journal of Geodynamics for inviting us to write this review article and two anonymous reviewers for their comments. AMT was partially supported by U.S. National Science Foundation grants 1130013, 1147975, and 1355878. This is Geological Survey of Canada contribution 20150275.

\section{References}

Adams, J., 1990. Paleoseismicity of the Cascadia subduction zone: Evidence from turbidites off the Oregon-Washington margin. Tectonics 9(4), 569-583, doi:10.1029/TC009i004p00569.

Atwater, B.F., 1987. Evidence for great Holocene earthquakes along the outer coast of Washington State. Science 236, 942-944.

Atwater. B.F., Carson, B., Griggs, G.B., Johnson, H.P., Salmi, M.S., 2014. Rethinking turbidite paleoseismology along the Cascadia subduction zone. Geology, dio:10.1130/G35902.1.

Atwater, B.F., Satoko, M.-R., Kenji, S., Yoshinobu, T., Kazue, U., Yamaguchi, D.K., 2005. The 
Orphan Tsunami of 1700: Japanese Clues to a Parent Earthquake in North America, edited by U.S. Geological Survey, U.S. Geol. Surv. and Univ. of Wash. Press.

Audet, P., Kim, Y., 2016. Teleseismic constraints on the geological environment of deep episodic slow earthquakes in subduction zone forearcs: A review. Tectonophys. 670, 1-16, doi:10.1016/j.tecto.2016.01.005.

Audet, P., Bostock, M.G., Christensen, N.I., Peacock, S.M., 2009. Seismic evidence for overpressured subducted oceanic crust and megathrust fault sealing. Nature 457, 76-78, doi: 10.1038/nature07650.

Baba, T., Cummins, P.R., 2005. Contiguous rupture areas of two Nankai Trough earthquakes revealed by high-resolution tsunami waveform inversion. Geophys. Res. Lett. 32, L08305, doi:10.1029/2004GL022320.

Baba, T., Cummins, P.R., Hori, T., Kaneda, Y., 2006. High precision slip distribution of the 1944 Tonankai earthquake inferred from tsunami waveforms: Possible slip on a splay fault. Tectonophys. 426, $119-134$.

Bachmann, R., Oncken, O., Glodny, J., Seifert, W., Georgieva, V., Sudo, M., 2009. Exposed plate interface in the European Alps reveals fabric styles and gradients related to an ancient seismogenic coupling zone. J. Geophys. Res. 114, B05402, doi:10.1029/2008JB005927.

Blanpied, M.L., Lockner, D.A., Byerlee, J.D., 1991. Fault stability inferred from granite sliding experiments at hydrothermal conditions. Geophys. Res. Lett. 18, 609-612, doi:10.1029/91GL00469.

Booth-Rea, G., Klaeschen, D., Grevemeyer, I., Reston, T., 2007. Heterogeneous deformation in the Cascadia convergent margin and its relation to thermal gradient (Washington, NW USA). Tectonics 27, TC4005, doi:10.1029/2007TC002209.

Boyarko, D.C., Brudzinski, M.R., Porritt, R.W., Allen, R.M., Tréhu, A.M., 2015. Automated detection and location of tectonic tremor along the entire Cascadia margin from 2005 to 2011. Earth Planet. Sci. Lett. 430, 160-170.

Bostock, M.G., Hyndman, R.D., Rondenay, S., Peacock, S.M., 2002. An inverted continental Moho and serpentinization of the forearc mantle. Nature 417, 536-538. doi:10.1038/417536a.

Bostock, M.G., Royer, A.A., Hearn, E.H., Peacock, S.M., 2012. Low frequency earthquakes below southern Vancouver Island. Geochem. Geophys. Geosyst. 13, 11, doi:10.1029/2012GC004391.

Briggs, R.W., et al., 2006. Deformation and slip along the Sunda Megathrust in the great 2005 Nias-Simeulue earthquake. Science 311, 1897-1901, doi:10.1126/science.1122602.

Brocher, T.M., Parsons, T., Tréhu, A.M., Snelson, C.M., Fisher, M.A., 2003. Seismic evidence for widespread serpentinized forearc upper mantle along the Cascadia margin. Geology 31, 267-270, doi:10.1130/0091-7613(2003)031<0267:SEFWSF>2.0.CO;2.

Brudzinski, M.R., Allen, R.M., 2007. Segmentation in episodic tremor and slip all along Cascadia. Geology 35(10), 907-910.

Burgette, R.J., Weldon, R., Schmidt, D.A., 2009. Interseismic uplift rates for western Oregon and along strike variation in locking on the Cascadia subduction zone. J. Geophys. Res. 114, 
B01408, doi:10.1029/2008JB005679.

Burgmann, R., Chadwell, D., 2014. Seafloor Geodesy. Annu. Rev. Earth Planet. Sci. 42, 509534, doi:10.1146/annurev-earth-060313-054953.

Chapman, J.S., Melbourne, T.I., 2009. Future Cascadia megathrust rupture delineated by episodic tremor and slip. Geophys. Res. Lett. 36, L22301, doi:10.1029/2009GL040465.

Cherniawsky, J.Y., Titov, V.V., Wang, K., Li, J.-Y., 2007. Numerical simulations of tsunami waves and currents for southern Vancouver Island from a Cascadia megathrust earthquake. Pure Appl. Geophys. 164, 465-492.

Chlieh, M., 2011. Interseismic coupling and seismic potential along the Central Andes subduction zone. J. Geophys. Res. 116, B12405, doi:10.1029/2010JB008166.

Cozzens, B.D., Spinelli, G.A., 2012. A wider seismogenic zone at Cascadia due to fluid circulation in subducting oceanic crust. Geology 40, 899-902, doi:10.1130/G33019.1.

Currie, C.A., Wang, K., Hyndman, R.D., He, J., 2004. The thermal effects of slab-driven mantle flow above a subducting plate: The Cascadia subduction zone and backarc. Earth Planet. Sci. Lett. 223, 35-48.

Davis, E.E., Wang, K., He, J., Chapman, D., Villinger, H., Rosenberger, A., 1997. An unequivocal case for high Nusselt number hydrothermal convection in sediment-buried igneous oceanic crust. Earth Planet. Sci. Lett. 146, 137-150.

Demets, C., Gordon, R.G., Argus, D.F., 2010. Geologically current plate motions. Geophys. J. Int. 181, 1-80, doi: 10.1111/j.1365-246X.2009.04491.x.

Di Toro, G. et al., 2011. Fault lubrication during earthquakes. Nature 427 (6973), 436-439.

Dragert, H., Wang, K., 2011. Temporal evolution of an ETS event along the northern Cascadia margin. J. Geophys. Res. 116, B12406, doi:10.1029/2011JB008609.

Dragert, H., Wang, K., James, T. S., 2001. A silent slip event on the deeper Cascadia subduction interface. Science 292, 1525-1528.

Emry, E.L., Wiens, D.A., Shiobara, H., Sugioka, H., 2011. Seismogenic characteristics of the Northern Mariana shallow thrust zone from local array data. Geochem. Geophys. Geosyst. 12, Q12008, doi :10.1029/2011GC003853.

Engelhart, S.E., Horton, B.P., Vane, C.H., Nelson, A.R., Witter, R.C., Brody, S.R. Hawkes, A.D., 2013. Modern foraminifera, $\delta^{13} \mathrm{C}$, and bulk geochemistry of central Oregon tidal marshes and their application in paleoseismology. Palaeogeography, Palaeoclimatology, Palaeoecology 377, 13-17.

Faulkner, D.R., Mitchell, T.M., Behnsen, J., Hirose, T., Shimamoto, T., 2011. Stuck in the mud? Earthquake nucleation and propagation through accretionary forearcs. Geophys. Res. Lett. 38, L18303, doi:10.1029/2011GL048552.

Fisher, M., Michael, A., Hyndman, R.D., Johnson, S.Y., Brocher, T.M., Crosson, R.S., Wells, R.E., Calvert, A.J., ten Brink, U.S., 2006. Crustal structure and earthquake hazards of the subduction zone in southwestern British Columbia and western Washington, in Kayen, R., ed., Earthquake hazards of the Pacific Northwest costal and marine regions: USGS Professional Paper 1661-C. 
Flueh, E. R., et al., 1998. New seismic images of the Cascadia subduction zone from cruise SO108-ORWELL. Tectonophys. 293, $69-84$.

Fujiwara, T., Kodaira, S., No, T., Kaiho, Y., Takahashi, N., Kaneda, Y., 2011. The 2011 Tohoku-oki earthquake: Displacement reaching the trench axis. Science 334, 1240, doi:10.1126/science.1211554.

Fukao, Y., 1997. Tsunami earthquakes and subduction processes near deep-sea trenches. J. Geophys. Res. 84(5), 2303-2314.

Flück, P., Hyndman, R.D., Wang, K., 1997. 3-D dislocation model for great earthquakes of the Cascadia subduction zone. J. Geophys. Res. 102, 20,539-20,550.

Gagnon, K., Chadwell, C.D.,Norabuena, E., 2005. Measuring the onset of locking in the PeruChile trench with GPS and acoustic measurements. Nature 434(7030), 205-208, doi:10.1038/nature03412.

Gao, X., Wang, K., 2014. Strength of stick-slip and creeping subduction megathrusts from heat flow observations. Science 345, 1038-1041. doi:10.1126/science.1255487

Gao, X., Wang, K., Wada, I., He, J., 2015. On the rheology of slow slip events around continental Moho. American Geophysical Union Fall meeting Fall meeting Abstract T31C2902, San Francisco.

Goldfinger, C., Kulm, L.V.D., McNeill, L.C, Watts, P., 2000. Super-scale failure of the southern Oregon Cascadia margin. Pure Appl. Geophys. 157(6-8), 1189-1226.

Goldfinger, C., et al., 2012. Turbidite event history: Methods and implications for Holocene paleoseismicity of the Cascadia subduction zone. U.S. Geol. Surv. Prof. Pap., 1661-F.

Goldfinger, C., Hamilton, T.S., Beeson, J., Galer, S., Nelson, C.H., Patton, J.R., Udrekh, Morey, A., 2014. Turbidite paleoseismology: Site Selection, physiography, sediment supply, current dynamics and temporal considerations as applied in Cascadia and elsewhere. American Geophysical Union Fall meeting Fall meeting Abstract T52-08, San Francisco.

Gomberg, J., and the Cascadia 2007 and Beyond Working Group, 2010. Slow-slip Phenomena in Cascadia from 2007 and Beyond: A Review. Geol. Soc. Am. Bull. 122(7/8), 963-978, doi: 10.1130/B30287.1.

Hashimoto, C., Noda, A., Sagiya, T., Matsu'ura, M., 2009. Interplate seismogenic zones along the Kuril-Japan trench inferred from GPS data inversion. Nature Geosci. 2, 141-145, doi:10.1038/NGEO421.

Hawkes, A.D., Horton, B.P., Nelson, A.R., Vane, C.H., Sawai, Y., 2011. Coastal subsidence in Oregon, USA, during the giant Cascadia earthquake of AD 1700. Quat. Sci. Rev. 30, 364376, doi:10.1016/j.quascirev.2010.11.017.

He, C., Wang, Z., Yao, W., 2007. Frictional sliding of gabbro gouge under hydrothermal conditions. Tectonophys. 445, 353-362, doi:10.1016/j.tecto.2007.09.008.

He, C., Luo, L., Hao, Q.-M., Zhou, Y., 2013. Velocity-weakening behavior of plagioclase and pyroxene gouges and stabilizing effect of small amounts of quartz under hydrothermal conditions. J. Geophys. Res. 118, 3408-3430, doi:10.1002/jgrb.50280.

Hetland, E.A., Simons, M., 2010. Post-seismic and interseismic fault creep II: transient creep and 
interseismic stress shadows on megathrusts. Geophys. J. Int. 181, 99-112, doi: 10.1111/j.1365-246X.2009.04482.x.

Hill, E.M., et al., 2012. The $2010 \mathrm{Mw} 7.8$ Mentawai earthquake: Very shallow source of a rare tsunami earthquake determined from tsunami field survey and near-field GPS data. J. Geophys. Res. 117, B06402, doi:10.1029/2012JB009159.

Holbrook, W.S., Kent, G., Keranen, K., Johnson, H.P., Tréhu, A., Tobin, H., Caplan-Auerbach, J. Beeson, J., 2012. Cascadia forearc seismic survey: open-access data available, EOS, Trans. Am. Geophys. Soc. 93(50), 521-522.

Hsu, Y.-J., Simons, M., Avouac, J.-P., Galetzka, J., Sieh, K., Chlieh, M., Natawidjaja, D., Prawirodirdjo, L., Bock, Y., 2006. Frictional afterslip following the 2005 Nias-Simeulue earthquake, Sumatra. Science 312, 1921-1926, doi:10.1126/science.1126960.

$\mathrm{Hu}$, Y., Wang, K., 2008. Coseismic strengthening of the shallow portion of the subduction fault and its effects on wedge taper, J. Geophys. Res. 113, B12411, doi:10.1029/2008JB005724.

Hu, Y., Wang, K., He, J., Klotz, J., Khazaradze, G., 2004. Three-dimensional viscoelastic finite element model for postseismic deformation of the great 1960 Chile earthquake. J. Geophys. Res. 109, B1240, doi:10.1029/2004JB003163.

Hubbard, J., Barbot, S., Hill, E.M., Tapponnier, P., 2015. Coseismic slip on shallow décollement megathrusts: implications for seismic and tsunami hazard. Earth-Sci. Rev. 141, 45-55.

Hutchinson, I., Guilbault, J.-P., Clague, J.J., Bobrowsky, P.T., 2000. Tsunamis and tectonic deformation at the northern Cascadia margin: A 3000-year record from Deserted Lake, Vancouver Island, British Columbia, Canada. Holocene 10, 429-439.

Hyndman, R.D., 2013. Downdip landward limit of Cascadia great earthquake rupture. J. Geophys. Res. 118, 5530-5549, doi:10.1002/jgrb.50390.

Hyndman, R.D., Wang, K., 1993. Thermal constraints on the zone of major thrust earthquake failure - the Cascadia subduction zone. J. Geophys. Res., 98, 2039-2060.

Hyndman, R.D., Wang, K., 1995. The rupture zone of Cascadia great earthquakes from current deformation and thermal regime. J. Geophys. Res., 100, 22,133-22,154.

Hyndman, R.D., Spence, G.D., Yuan, T., Davis, E.E., 1994. Regional geophysics an structural framework of the Vancouver Island margin accretionary prims, in, Proceedings of the Ocean Drilling Program, Initial Reports, 146, College Station, TX (Ocean Drilling Program), 399419.

Hyndman, R.D., McCrory, P.A., Wech, A., Kao, H., Ague, J., 2015. Cascadia subducting plate fluids channelled to fore-arc mantle corner: ETS and silica deposition. J. Geophys. Res. 120, 4344-4358, doi:10.1002/2015JB011920.2015.

Hyndman, R.D., Wang, K., Yamano, M., 1995. Thermal constraints on the seismogenic portion of the southwestern Japan subduction thrust. J. Geophys. Res. 100, 15,373-15,392.

Ichinose, G.A., Thio, H.K., Somerville, P.G., Sato, T., Ishii, T., 2003. Rupture process of the 1944 Tonankai earthquake (Ms 8.1) from the inversion of teleseismic and regional seismograms. J. Geophys. Res. 108(B10), 2497, doi:10.1029/2003JB002393.

Kobayashi, A., 2010. A small scale long-term slow slip occurred in the western Shikoku in 2005. 
J. Seismol. Soc. Jpn 63, 97-100 [in Japanese with English abstract].

Kobayashi, A., 2012. Long-term slow slip event around Kochi City from 1977 to 1980. J.

Seismol. Soc. Jpn 64, 63-73 [in Japanese with English abstract].

Kobayashi, A., 2014. A long-term slow slip event from 1996 to 1997 in the Kii Channel, Japan. Earth, Planets Space 66:9.

Kao, H., Shan, S.-J., Dragert, H., Rogers, G., Cassidy, J.F., Ramachandran, K., 2005. A wide depth distribution of seismic tremors along the northern Cascadia margin. Nature 436, 841844, doi:10.1038/nature03903.

Kato, A., et al., 2010. Variations of fluid pressure within the subducting oceanic crust and slow earthquakes. Geophys. Res. Lett. 37, L14310, doi:10.1029/2010GL043723.

Kimura, G., Yamaguchi, A., Hojo, M., Kitamura, Y., Kameda, J., Ujiie, K., Hamada, Y., Hamahashi, M., Hina, S., 2012. Tectonic mélange as fault rock of subduction plate boundary. Tectonophys. 568-569, 25-38, doi:10.1016/j.tecto.2011.08.025.

Kirby, S. H., Wang, K., Brocher, T. M., 2014. A large mantle water source for the northern San Andreas fault system: a ghost of subduction past. Earth Planets Space 66:67. doi:10.1186/1880-5981-66-67

Kodaira, S., No, T., Nakamura, Y., Fujiwara, T., Kaiho, Y., Miura, S., Takahashi, N., Kaneda, Y., Taira, A., 2012. Coseismic fault rupture at the trench axis during the 2011 Tohoku-oki earthquake. Nat. Geosci. 5, 646-650, doi:10.1038/ngeo1547.

Kozdon, J.E., Dunham, E.M., 2013. Rupture to the Trench: Dynamic Rupture Simulations of the 11 March 2011 Tohoku Earthquake. Bull. Seismol. Soc. Am. 103(2B), 1275-1289, doi:10.1785/0120120136.

Lay, T., 2015. The surge of great earthquakes from 2004 to 2014. Earth Planet. Sci. Lett. 409, 133-146, 2015.

Leonard, L.J., Currie, C.A., Mazzotti, S., Hyndman, R.D., 2010. Rupture area and displacement of past Cascadia great earthquakes from coastal coseismic subsidence. Geol. Soc. Am. Bull., 122(11-12), 2079-2096, doi:10.1130/B30108.1.

Li, S., Moreno, M., Bedford, J., Rosenau, M., Oncken, O., 2015. Revisiting viscoelastic effects on interseismic deformation and locking degree: A case study of the Peru-North Chile subduction zone. J. Geophys. Res. 120, doi:10.1002/2015JB011903.

Liu, Y., 2013. Numerical simulations on megathrust rupture stabilized under strong dilatancy strengthening in slow slip region. Geophys. Res. Lett. 40, 1311-1316, doi:10.1002/grl.50298.

Liu, Y., Rice, J.R., 2009. Slow slip predictions based on granite and gabbro friction data compared to GPS measurements in northern Cascadia. J. Geophys. Res. 114, B09407, doi: 10.1029/2008JB006142.

Loveless, J.P., Meade, B.J., 2010. Geodetic imaging of plate motions, slip rates, and partitioning of deformation in Japan. J. Geophys. Res. 115, B02410, doi:10.1029/2008JB006248.

Ludwin, R.S. et al., 2005. Dating the 1700 Cascadia Earthquake: Great Coastal Earthquakes in Native Stories. Seismol. Res. Lett. 76(2), 140-148.

MacKay, M., 1995. Structural variation and landward vergence at the toe of the Oregon accretionary prism. Tectonics 14, $1309-1320$. 
Marone, C., 1998. Laboratory-derived friction laws and their application to seismic faulting. Ann. Rev. Earth Planet. Sci. 26, 649-696.

Meade, B. J., Loveless, J. P., 2009. Predicting the geodetic signature of Mw $\geq 8$ slow slip events. Geophysical Research Letters. Geophys. Res. Lett. 36, 1-5, doi: 10.1029/2008GL036364.

McCaffrey, R., King, R.W., Payne, S.J., Lancaster, M., 2013. Active tectonics of northwestern U.S. inferred from GPS-derived surface velocities, J. Geophys. Res. 118, 709-723, doi:10.1029/2012JB009473.

McCaffrey, R., Qamar, A., King, R., Wells, R.E., Khazaradze, G., Williams, C.A., Stevens, C.W., Vollick, J.J., Zwick, P.C., 2007. Fault locking, block rotation and crustal deformation in the Pacific Northwest. Geophys. J. Int. 169, 1315-1340.

McCaffrey, R., Wallace, L.M., Beavan, J., 2008. Slow slip and frictional transition at low temperature at the Hikurangi subduction zone. Nature, Geosci. 1, 316-320.

McCrory, P.A., Blair, L., Oppenheimer, D.H., Walter, S.R., 2004. Depth to the Juan de Fuca Slab Beneath the Cascadia Subduction Margin-A 3-D Model for Sorting Earthquakes, Vol. 91, 22 pp., U. S. Geol. Surv.

McCrory, P.A., Blair, J.L., Waldhauser, F., Oppenheimer, D. H., 2012. Juan de Fuca slab geometry and its relation to Wadati-Benioff zone seismicity. J. Geophys. Res. 117, B09306, doi:10.1029/2012JB009407.

McCrory, P.A., Hyndman, R.D., Blair, J.L., 2014. Relationship between the Cascadia fore-arc mantle wedge, nonvolcanic tremor, and the downdip limit of seismogenic rupture. Geochem. Geophys. Geosyst., 15, 1071-1095, doi:10.1002/2013GC005144.

Mitchell, E.K., Fialko, Y., Brown, K.M., 2015. Frictional properties of gabbro at conditions corresponding to slow slip events in subduction zones. Geochem. Geophys. Geosyst. 16, 4006-4020, doi:10.1002/2015GC006093.

Morton, E.A., Bilek, S.L., 2015. Preliminary event detection of earthquakes using the Cascadia Initiative data. Seismol. Res. Lett. 86(5), 1270-1277, doi: 10.1785/0220150098.

Murray, J., Langbein, J., 2006. Slip on the San Andreas Fault at Parkfield, California, over two earthquake cycles, and the implications for seismic hazard. Bull. Seismol. Soc. Am. 96, S283-S303, doi:10.1785/0120050820.

Newman, A.V., Hayes, G., Wei, Y., Convers, J., 2011. The 25 October 2010 Mentawai tsunami earthquake, from real-time discriminants, finite fault rupture, and tsunami excitation. Geophys. Res. Lett. 38, L05302, doi:10.1029/2010GL046498.

Noda, H., Lapusta, N., 2013. Stable creeping fault segments can become destructive as a result of dynamic weakening. Nature 493, 518-521, doi:10.1038/nature11703.

Obana, K., M. Scherwath, Y. Yamamoto, S. Kodaira, K. Wang, G. Spence, M. Riedel, and H. Kao (2015), Earthquake activity in northern Cascadia subduction zone off Vancouver Island revealed by ocean bottom seismograph observations, Bull. Seismol. Soc. Am., 150(1), 489495.

Obara, K., 2002. Nonvolcanic deep tremor associated with subduction in southwest Japan, Science 296, 1679-1681, doi:10.1126/science.1070378. 
Obara, K., 2010. Phenomenology of deep slow earthquake family in southwest Japan: Spatiotemporal characteristics and segmentation. J. Geophys. Res. 115, B00A25, doi:10.1029/2008JB006048.

Obara, K., 2011. Characteristics and interactions between non-volcanic tremor and related slow earthquakes in the Nankai subduction zone, southwest Japan. J. Geodynamics 52, 229-248.

Oppenheimer, D., et al., 1993. The Cape Mendocino, California, earthquake sequence of April, 1992: Subduction at the triple junction, Science 261,433-438.

Ozawa, S., Yarai, H., Imakiire, T., Tobita, M., 2013. Spatial and temporal evolution of the long-term slow slip in the Bungo Channel, Japan. Earth Planets Space 65(2), 67-73, doi:10.5047/eps.2012.06.009

Peng, Z., Gomberg, J., 2010. An integrated perspective of the continuum between earthquakes and slow-slip phenomena. Nat. Geosci. 3, 599-607.

Peng, Z., Vidale, J.E., Wech, A.G., Nadeau, R.M., Creager, K.C., 2009. Remote triggering of tremor along the San Andreas Fault in central California. J. Geophys. Res. 114, B00A06, doi:10.1029/2008JB006049.

Plafker, G., 1972. Tectonics, in The Great Alaska Earthquake of 1964, Seismology and Geodesy, pp. 113-188, Natl. Acad. of Sci., Washington, D.C.

Pollitz, F.F., McCrory, P., Wilson, D., Svarc, J., Puskas, C., Smith, R.B., 2010. Viscoelasticcycle model of interseismic deformation in the northwestern United States. Geophys. J. Int. 181, 665-696, doi:10.1111/j.1365-246X.2010.04546.x.

Priest, G.P., Goldfinger, C., Wang, K., Witter, R.C., Zhang, Y., Baptista, A.M., 2010.

Confidence levels for tsunami-inundation limits in northern Oregon inferred from a 10,000year history of great earthquakes at the Cascadia subduction zone. Nat. Hazards 54(1), $27-$ 73, doi:10.1007/s11069-009-9453-5.

Protti, M., Gonzalez, V., Newman, A.V., et al., 2013. Nicoya earthquake rupture an-ticipated by geodetic measurement of the locked plate interface. Nat. Geosci. 7(2), 117-121, http://dx.doi.org/10.1038/ngeo2038.

Rogers, G., Dragert, H., 2003. Episodic tremor and slip on the Cascadia subduction zone: The chatter of silent slip. Science 300, 1942-1943.

Rotman, H.M.M., Spinelli, G.A., 2014. Remarkably consistent thermal state of the south central Chile subduction zone from $36^{\circ} \mathrm{S}$ to $45^{\circ} \mathrm{S}$. J. Geophys. Res. 119, doi:10.1002/2013JB010811.

Rowe, C.D., Moore, J.C., Remitti, F., the IODP Expedition 343/343T Scientists, 2013. The thickness of subduction plate boundary faults from the seafloor into the seismogenic zone. Geology 41, 991-994, doi:10.1130/G34556.1.

Royer, A.A., Bostock, M.G., 2014. A comparative study of low frequency earthquake templates in northern Cascadia. Earth Planet. Sci. lett. 402, 247-256.

Ryan, W.B.F., et al., 2009. Global Multi-Resolution Topography synthesis. Geochem. Geophys. Geosyst. 10, Q03014, doi:10.1029/2008GC002332.

Sagiya, T., Thatcher, W., 1999. Coseismic slip resolution along a plate boundary megathrust:

The Nankai Trough, southwest Japan. J. Geophys. Res. 104(B1), 1111-1129, doi:10.1029/98JB02644. 
Satake, K., Wang, K., Atwater, B.F., 2003. Fault slip and seismic moment of the 1700 Cascadia earthquake inferred from Japanese tsunami descriptions. J. Geophys. Res. 108(B11), 2535, doi:10.1029/2003JB002521.

Savage, J.C., A dislocation model of strain accumulation and release at a subduction zone. J. Geophys. Res. 88, 4984- 4996, 1983.

Schmalzle, G.M., McCaffrey, R., Creager, K.C., 2014. Central Cascadia subduction zone creep. Geochem. Geophys. Geosyst. 15, 1515-1532, doi:10.1002/2013GC005172.

Scholl, D.W., Kirby, S.H., von Huene, R., Ryan, H., Wells, R.E., Geist, E.L., 2015, Great ( $\geq$ Mw8.0) megathrust earthquakes and the subduction of excess sediment and bathymetrically smooth seafloor. Geosphere 11(2), 236-265, doi:10.1130/GES01079.1.

Scholz, C.H., 1998. Earthquakes and friction laws. Nature 391, 37- 42.

Scholz, C.H., 2002. The Mechanics of Earthquakes and Faulting ( $2^{\text {nd }}$ Edition). Cambridge University Press, Cambridge, 471 p.

Schwartz, S.Y., Rokosky, J.M., 2007. Slow slip events and seismic tremor at circum-pacific subduction zones. Rev. Geophys. 45, RG3004, doi:10.1029/2006RG000208.

Sekine, S., Hirose, H., Obara, K., 2010. Along-strike variations in short-term slow slip events in the southwest Japan subduction zone. J. Geophys. Res. 115, B00A27, doi:10.1029/2008JB006059.

Shelly, D.R., Beroza, G.C., Ide, S., 2007. Non-volcanic tremor and low-frequency earthquake swarms. Nature 446 305-307. http://dx.doi.org/10.1038/nature05666.

Shelly, D.R., Hardebeck, J.L., 2010. Precise tremor source locations and amplitude variations along the lower-crustal central San Andreas Fault. Geophys. Res. Lett. 37, doi:10.1029/i2010GL043672.

Shimamoto, T., Noda, H., 2014. A friction to flow constitutive law and its application to a 2-D modeling of earthquakes. J. Geophys. Res. 119, 8089-8106, doi:10.1002/2014JB011170.

Sclater, J.G., Variability of heat flux through the seafloor: discovery of hydrothermal circulation in the oceanic crust, in Davis, E.E., and Elderfi eld, H., eds., Hydrogeology of the ocean lithosphere: New York, Cambridge University Press, p. 3-27.

Spinelli, G.A., Wang, K., 2008. Effects of fluid circulation in subducting crust on seismogenic zone temperatures. Geology 36(11), 887-890.

Stein, S., Okal, E.A., 2007. Ultralong period seismic study of the December 2004 Indian Ocean earthquake and implications for regional tectonics and the subduction process. Bull. Seismol. Soc. Am. 97, S279-S295, doi:10.1785/0120050617.

Sun, T., Wang, K., Iinuma, T., Hino, H., He, J., Fujimoto, H., Kido, M., Osada, Y., Miura, S., Ohta, Y., Hu, Y., 2014. Prevalence of viscoelastic relaxation after the 2011 Tohoku-oki earthquake, Nature, 513, 84-87. Doi:10.1038/nature13778

Suwa, Y., Miura, S., Hasegawa, A., Sato, T., Tachibana, K., 2006. Interplate coupling beneath NE Japan inferred from three-dimensional displacement field. J. Geophys. Res. 111, B04402, doi:10.1029/2004JB003203.

Takagi, R., Obara, K., Maeda, T., 2015. Slow slip event within a gap between tremor and locked zones in the Nankai subduction zone. Geophys. Res. Lett. 43, doi:10.1002/2015GL066987. 
Thatcher, W., 1984. The earthquake deformation cycle at the Nankai Trough, southwest Japan. J. Geophys. Res. 89(B5), 3087-3101.

Thatcher, W., Rundle, J.B, 1984. A viscoelastic coupling model for the cyclic deformation due to periodically repeated earthquakes at subduction zones. J. Geophys. Res. 89, 7631-7640.

Toomey, D.R. et al., 2014. The Cascadia Initiative: A sea change in seismological studies of subduction zones. Oceanography 27(2),138-150, http://dx.doi.org/10.5670/oceanog.2014.49.

Tréhu, A.M., Asudeh, I., Brocher, T.M., Luetgert, J.H., Mooney, W.D., Nabelek, J.L., Nakamura, Y., 1994. Crustal architecture of the Cascadia forearc. Science 266, 237-243.

Tréhu, A.M., Blakely, R.J., Williams, M.C., 2012. Subducted seamounts and recent earthquakes beneath the central Cascadia forearc. Geology 40, 103-106, doi:10.1130/G32460.1.

Tréhu, A.M., Braunmiller, J., Nabelek, J.L., 2008. Probable low-angle thrust earthquakes on the Juan de Fuca-North America plate boundary. Geology 36, 127-130, doi:10.1130/G24145A.1.

Tréhu, A.M., Braunmiller, J., Davis, E., 2015. Seismicity of the central Cascadia continental margin near $44.5^{\circ} \mathrm{N}$ : a decadal view. Seis. Res. Lett. 86, 819-829, doi: 10.1785/0220140207.

Wada, I., Wang, K., 2009. Common depth of slab-mantle decoupling: reconciling diversity and uniformity of subduction zones. Geochem. Geophys. Geosyst. 10, Q10009,

Wada, I., Wang, K., He, J., Hyndman, R.D., 2008. Weakening of the subduction interface and its effects on surface heat flow, slab dehydration, and mantle wedge serpentinization. J. Geophys. Res. 113, B04402, doi:10.1029/2007JB005190.

Waldhauser, F., Schaff, D.P., 2008. Large-scale relocation of two decades of Northern California seismicity using cross-correlation and double-difference methods. J. Geophys. Res. 113, B08311, doi:10.1029/2007JB005479.

Wallace, L.M., Beavan, J., 2010. Diverse slow slip behavior at the Hikurangi subduction margin, New Zealand. J. Geophys. Res. 115, B12402, doi:10.1029/2010JB007717.

Wallace, L.M., et al., 2009. Characterizing the seismogenic zone of a major plate boundary subduction thrust: Hikurangi margin, New Zealand. Geochem. Geophys. Geosyst. 10, Q10006, doi:10.1029/2009GC002610.

Wallace, L.M., et al., 2015. Seafloor geodetic and ocean bottom seismometer investigation of shallow slow slip events at the Hikurangi subduction margin, New Zealand, American Geophysical Union Fall meeting Fall meeting Abstract S33E-06, San Francisco (https://agu.confex.com/agu/fm15/meetingapp.cgi/Paper/71324).

Wang, K., 2007. Elastic and viscoelastic models of subduction earthquake cycles. In: Dixon, T., Moore, C. (Eds.), The Seismogenic Zone of Subduction Thrust Faults. Columbia University Press, pp. 540-575.

Wang, K., Bilek, S.L., 2011. Do subducting seamounts generate or stop large earthquakes? Geology 39, 819-822, doi:10.1130/G31856.1.

Wang, K., Bilek, S.L., 2014. Invited review paper: Fault creep caused by subduction of rough seafloor relief. Tectonophys. 610, 1-24. 
Wang, K., Dixon, T., 2004. “Coupling” semantics and science in earthquake research. Eos Trans. $A G U, 85(18), 4$ May, page 180.

Wang, K., Gao, X., 2016. On the relationship between the seismogenic zone and the ETS zone. Abstract 94122, American Geophysical Union Chapman Conference on Slow Slip Phenomena, Ixtapa, Mexico, 21-25 February 2016 (https://agu.confex.com/agu/16chapman1/webprogram/Paper94122.html).

Wang, K., J. He, 2008. Effects of frictional behavior and geometry of subduction fault on coseismic seafloor deformation. Bull. Seismol. Soc. Am. 98(2), 571-579.

Wang, K., Hu, Y., 2006. Accretionary prisms in subduction earthquake cycles: The theory of dynamic Coulomb wedge. J. Geophys. Res. 111, B06410, doi:10.1029/2005JB004094.

Wang, K., Hu, Y., He, J., 2012a. Deformation cycles of subduction earthquakes in a viscoelastic Earth. Nature 484, 327-332, doi:10.1038/nature11032.

Wang, K., Wada, I., Ishikawa, Y., 2004. Stresses in the subducting slab beneath southwest Japan and relation with plate geometry, tectonic forces, slab dehydration, and damaging earthquakes. J. Geophys. Res. 109, B08304, doi:10.1029/2003JB002888.

Wang, K., Dragert, H., Kao, H., Roeloffs, E., 2008. Characterizing an "uncharacteristic' ETS event in northern Cascadia. Geophys. Res. Lett. 35, L15303, doi:10.1029/2008GL034415.

Wang, K., He, J., Schulzeck, F., Hyndman, R.D., Riedel, M., 2015. Thermal condition of the 27 October $2012 \mathrm{Mw}=7.8$ Haida Gwaii subduction earthquake at the obliquely convergent Queen Charlotte margin. Bull. Seismol. Soc. Am. 105(2B), 1290-1300.

Wang, K., Mulder, T., Rogers, G.C., Hyndman, R.D., 1995. Case for very low coupling stress on the Cascadia subduction fault. J. Geophys. Res. 100, 12,907-12,918.

Wang, K., Wells, R., Mazzotti, S., Hyndman, R.D., Sagiya, T., 2003. A revised dislocation model of interseismic deformation of the Cascadia subduction zone. J. Geophys. Res. 108, 2026, doi:10.1029/2001JB001227.

Wang, P.-L., Engelhart, S.E., Wang, K., Hawkes, A.D., Horton, B.P., Nelson, A.R., Witter, R.C., 2013. Heterogeneous rupture in the great Cascadia earthquake of 1700 inferred from coastal subsidence estimates. J. Geophys. Res. 118, 1-14, doi:10.1002/jgrb.50101.

Wang, Y., Wang, K., He, J., 2012b. On the possibility of interseismic creep of the Cascadia megathrust. American Geophysical Union Fall meeting Abstract T23E-2717, San Francisco.

Wech, A.G., Creager, K.C., 2011. A continuum of stress, strength and slip in the Cascadia subduction zone. Nature Geosci. 4(9), 624-628, doi:10.1038/NGEO1215.

Wells, R.E., Simpson, R.W., 2001. Northward migration of the Cascadia forearc in the northwestern U. S. and implications for subduction deformation. Earth Planets Space 53, 275-283, 2001.

Wells, R.E., Weaver, C.S., Blakely, R.J., 1998. Fore-arc migration in Cascadia and its neotectonic significance. Geology 26(8), 759-762.

Wells, R.E., Blakely, R.J., Sugiyama, Y., Scholl, D.W., Dinterman, P.A., 2003. Basin-centered asperities in great subduction zone earthquakes: A link between slip, subsidence, and subduction erosion? J. Geophys. Res. 108(B10), 2507, doi:10.1029/2002JB002072.2003.

Williams, M.C., Tréhu, A.M., Braunmiller, J., 2011. Seismicity at the Cascadia plate boundary 
beneath the Oregon continental shelf. Bull. Seis. Soc. Am. 101, 940-950.

Witter, R.C., Zhang, Y.J., Wang, K., Goldfinger, C., Priest, G.R., Allan, J.C., 2012. Coseismic slip on the southern Cascadia megathrust implied by tsunami deposits in an Oregon lake and earthquake-triggered marine turbidites. J. Geophys. Res. 117, B10303, doi:10.1029/2012JB009404.

Witter, R.C., Zhang, Y.J., Wang, K., Priest, G.R., Goldfinger, C., Stimely, L., English, J.T., Ferro, P.A., 2013. Simulated tsunami inundation for a range of Cascadia megathrust earthquake scenarios at Bandon, Oregon, USA. Geosphere 9(6), 1-21.

Wong, I.G., Chapman, D.S., 1990. Deep intraplate earthquakes in the western United States and their relationship to lithospheric temperatures. Bull. Seismol. Soc. Am. 80, 589-599.

Yue, H., Lay, T., Rivera, L., An, C., Vigny, C., Tong, X., Baez Soto, J.C., 2015. Localized fault slip to the trench in the 2010 Maule, Chile $\mathrm{M} \mathrm{w}=8.8$ earthquake from joint inversion of high-rate GPS, teleseismic body waves, InSAR, campaign GPS, and tsunami observations: Slip in the 2010 Maule, Chile earthquake, J. Geophys. Res. 119 (10), doi: 10.1002/2014JB011340. 


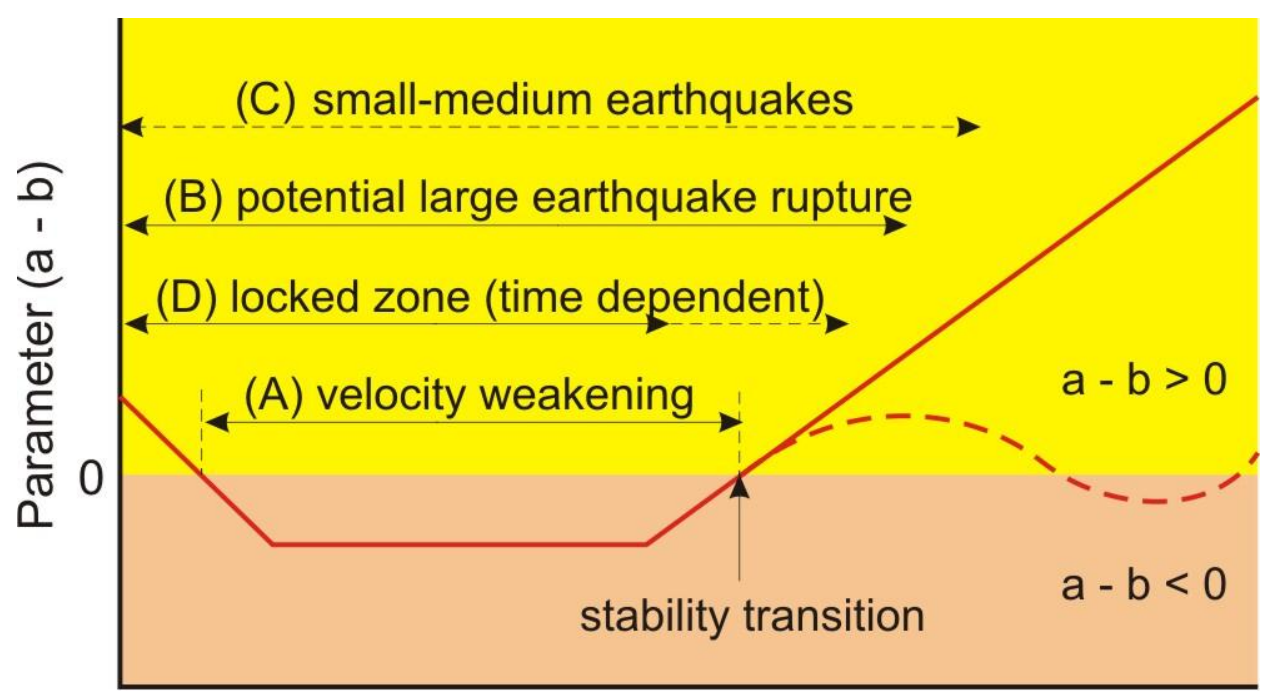

Downdip Distance

Fig. 1. Four definitions of the seismogenic zone in the context of rate-state friction as discussed in section 2.1. The zone of velocity-weakening $(a-b<0)$, commonly regarded as the "theoretical" seismogenic zone, is where earthquakes may nucleate. The actual seismic rupture, the "observed" seismogenic zone, may go far into the velocity-strengthening area due to low degrees of strengthening or dynamic weakening. Low-magnitude interplate seismicity may or may not occur over a broader depth range. The downdip width of the interseismically locked zone is difficult to constrain using geodetic observations and is seen to decrease with time in rate-state earthquake cycle models (section 5.1). Red-dashed line shows possible downdip variations in $(\mathrm{a}-\mathrm{b})$ in Cascadia and some other subduction zones, to be discussed in section 6. 



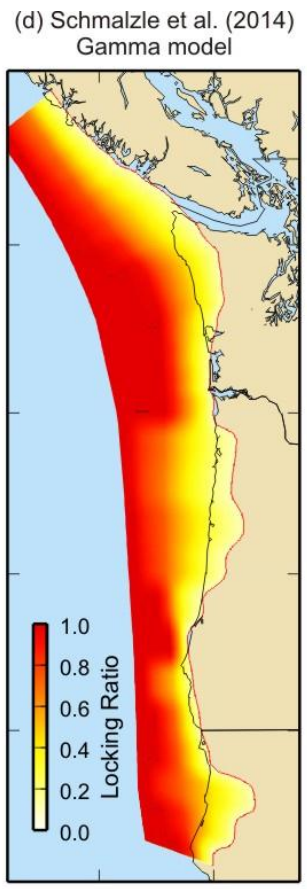

$126^{\circ} \mathrm{W} \quad 124^{\circ} \mathrm{W}$

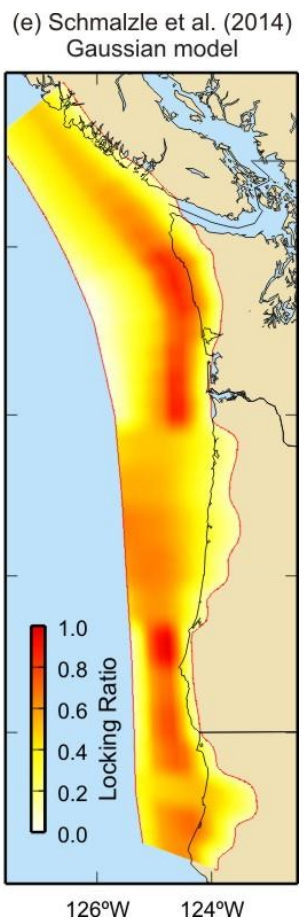

Fig. 2. Representative elastic dislocation models of Cascadia megathrust interseismic locking or coseismic rupture published over the last two decades. (a) Hyndman and Wang (1995): Uniform locking with linear downdip transition. There are various modified versions (e.g., Flück et al., 1997; Burgette et al., 2009). (b) Wang et al. (2003): Uniform locking with an effective transition zone (ETZ) to compensate for the missing effect of viscoelasticity. For modeling the AD 1700 trans-Pacific tsunami, coseismic rupture was assumed to have extended to the middle of ETZ (Satake et al., 2003). (c) Priest et al. (2010): Bell-shape downdip distribution of coseismic slip used as a tsunami source scenario. The apex of the "bell" is equivalent to 500 years of slip deficit. Shown is a simplified version in which the downdip rupture limit is the same as in (b). (d) Schmalzle et al. (2014) "Gamma" model: Full interseismic locking at deformation front with locking ratio monotonically decreasing landward. (e) Schmalzle et al. (2014) "Gaussian” model: Interseismic creep is allowed at the deformation front. Both (d) and (e) are updated versions of McCaffrey et al. (2012). 

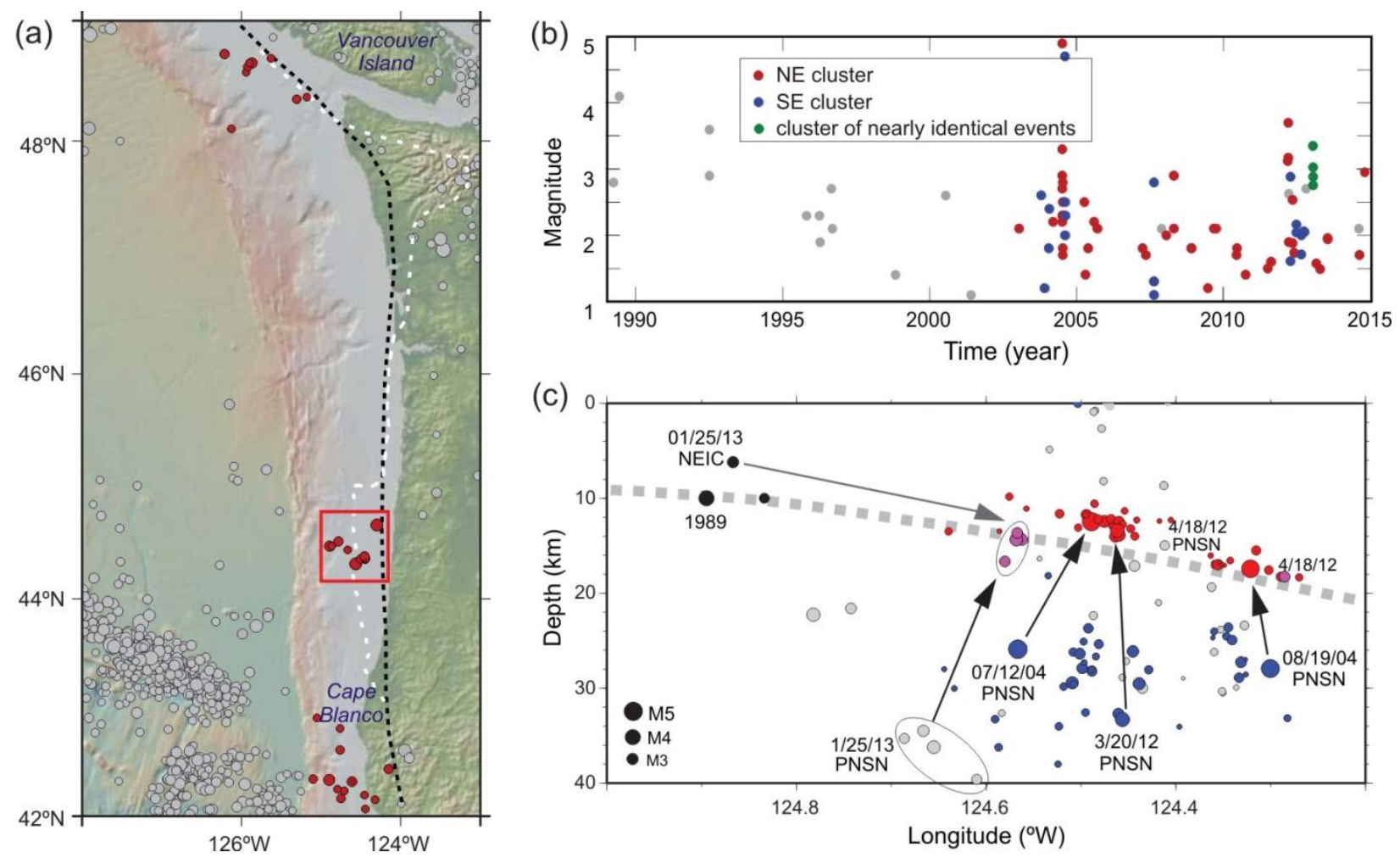

Fig. 3. Seismicity of the Cascadia subduction zone north of $42^{\circ} \mathrm{N}$ (adapted from Tréhu et al., 2015). (a) Map showing all earthquakes with $M>3$ in the Advanced National Seismic System (ANSS) catalog from 1989 through 2014. Circles are scaled by magnitude. Those between the deformation front (not marked but clearly defined by the change in elevation) and the $450^{\circ}$ isotherm on the subduction interface (dashed black line) from Hyndman and Wang (1995) are shown in red for emphasis. Except those in the red box off central Oregon, none of the events have been confirmed to be located along the plate interface. The region south of $42^{\circ} \mathrm{N}$, where there are many earthquakes that may originate either on the plate boundary or in the upper and lower plates, is not shown. The dashed white line shows the seaward edge of the mafic Siletz terrane (likely an accreted piece of over-thickened oceanic crust) (Wells et al. 1998; Tréhu et al., 2012). Red box outlines the region where data shown in (b) and (c) are obtained. Topography is from the Global Multi-Resolution Topography synthesis (Ryan et al., 2009) (http://www.geomapapp.org). (b) Magnitude versus time for all events in the ANSS catalog from the red box area showing persistence over several decades of seismicity in this region. Events shown in green occurred on a single day and had nearly identical waveforms (Tréhu et al., 2015). (c) East-west depth section across red box (from Tréhu et al., 2015). Blue dots are positions from the ANSS catalog at the Northern California Earthquake Data Center, University of California Berkeley Seismological Laboratory (doi:10.7932/NCEDC). Red and magenta dots show relocated positions (Tréhu et al., 2015). Arrows connect the catalog locations and the revised locations for the largest events. 

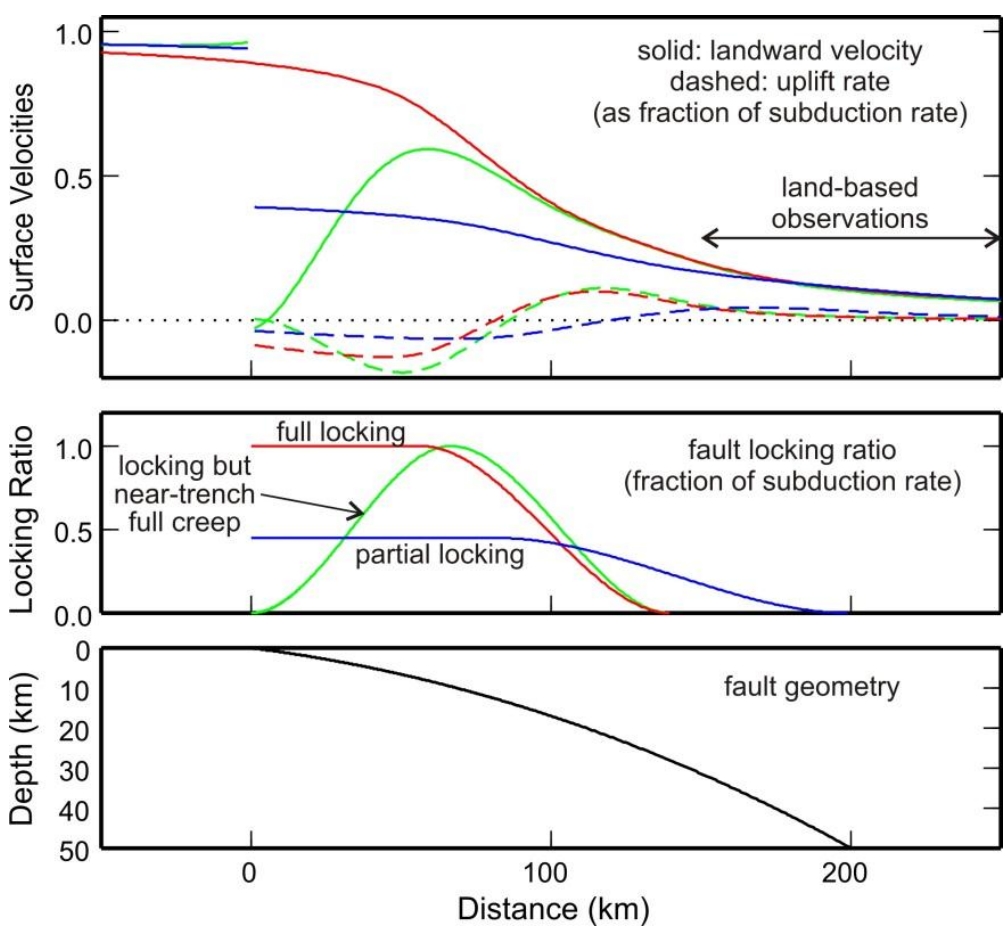

Fig. 4. Locking/creeping scenarios and resultant surface deformation based on a 2D elastic dislocation model, illustrating the importance of making seafloor geodetic observations. All the shown scenarios are difficult to differentiate using land-based geodetic observations, but they produce drastically different horizontal deformation signals around the "trench" (zero distance). Vertical rates seaward of the trench are sensitive to model artefacts and have been removed. 

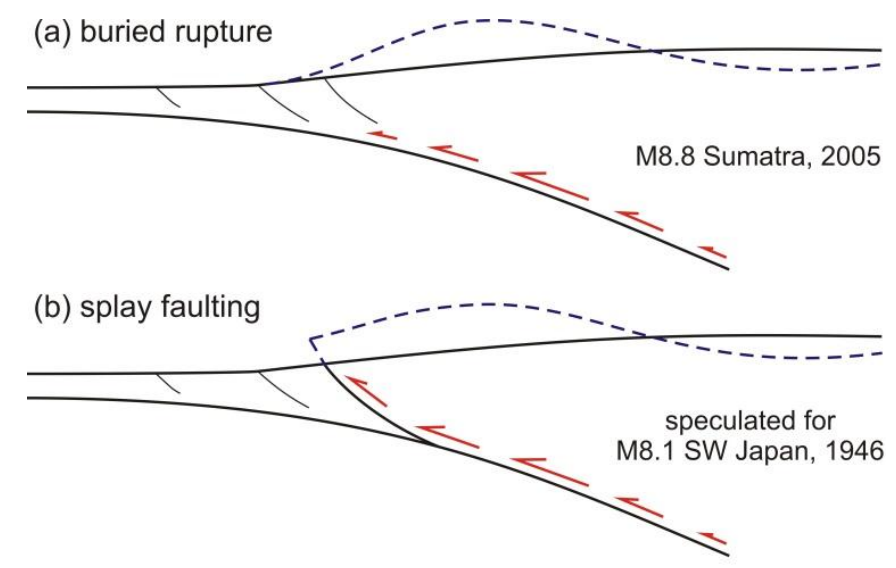

(c) trench-breaching
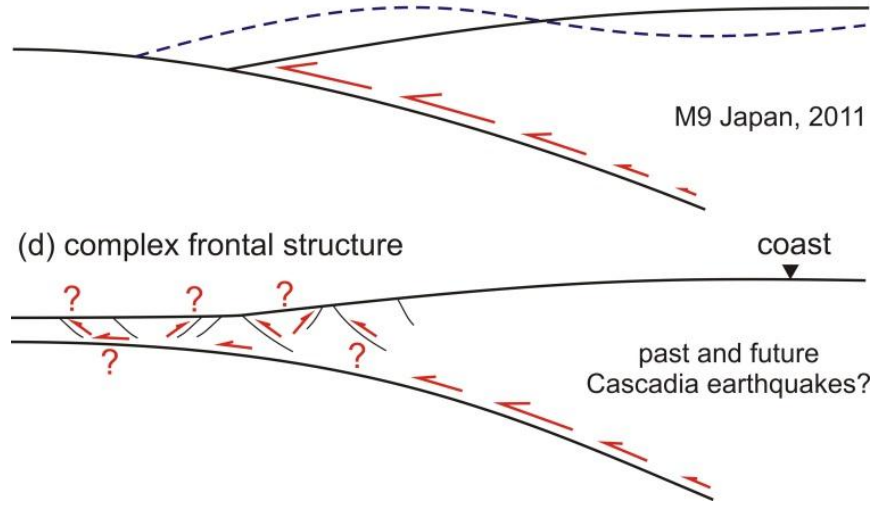

Fig. 5. Scenarios of shallowest part of megathrust rupture in great earthquakes. (a) Buried rupture as seen in the $2005 \mathrm{M}_{\mathrm{w}}=8.8$ Sumatra earthquake and assumed in the Cascadia model shown in Fig. 2c. (b) Mega-splay rupture as speculated for the $1946 \mathrm{M}_{\mathrm{w}}=8.1$ Nankaido earthquake and assumed in some Cascadia models of Satake et al. (2003), Priest et al. (2010), and Witter et al. (2013). (c) Trench-breaching rupture as seen in the $2011 \mathrm{M}_{\mathrm{w}}=9$ Tohoku-oki earthquake. (d) Difficulty in determining shallow rupture behaviour in a system of complex frontal structure as observed in most of the Cascadia margin. 

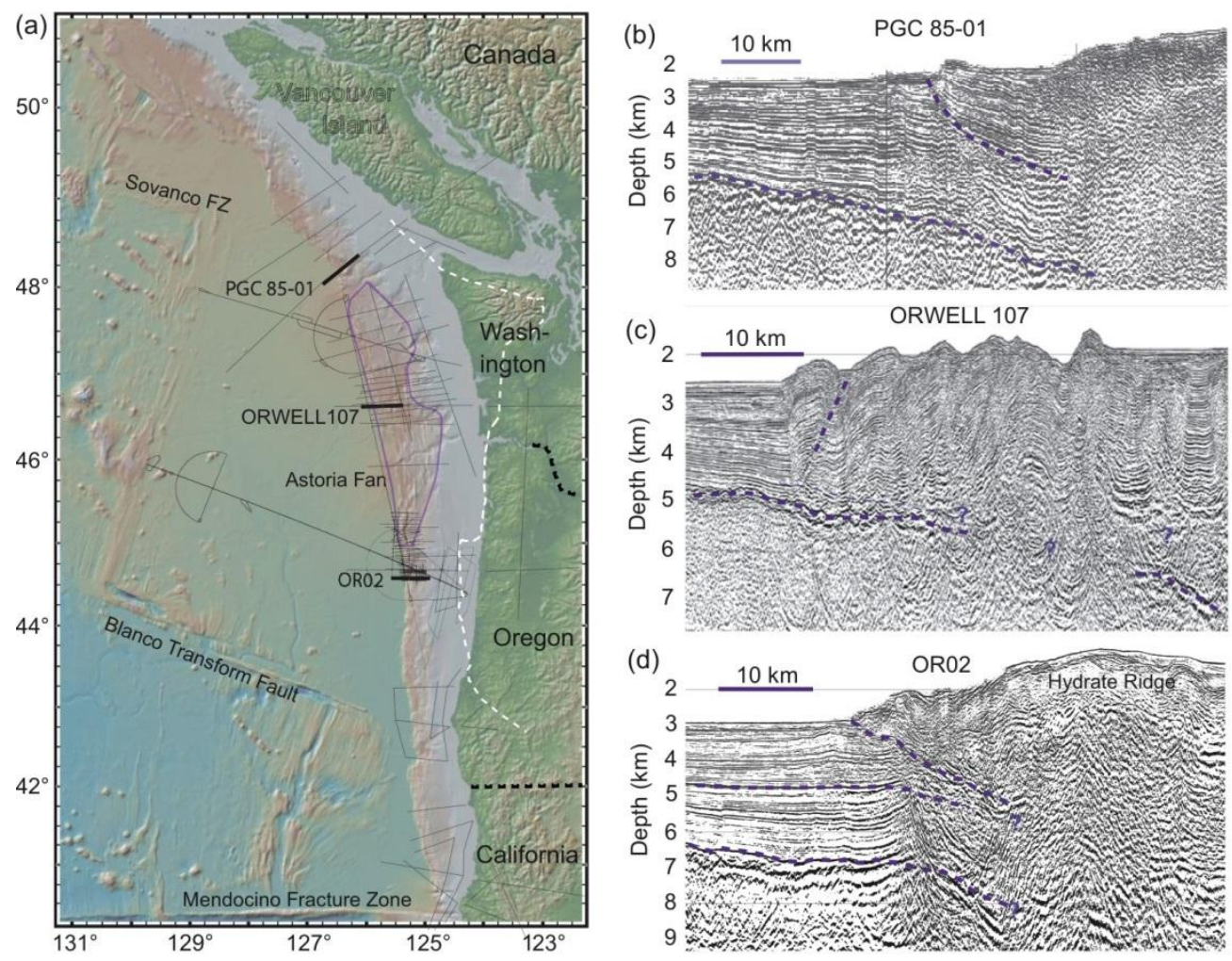
(e) $\circ$ water depth
$\bullet$ sediment thickness
- sediment thickness
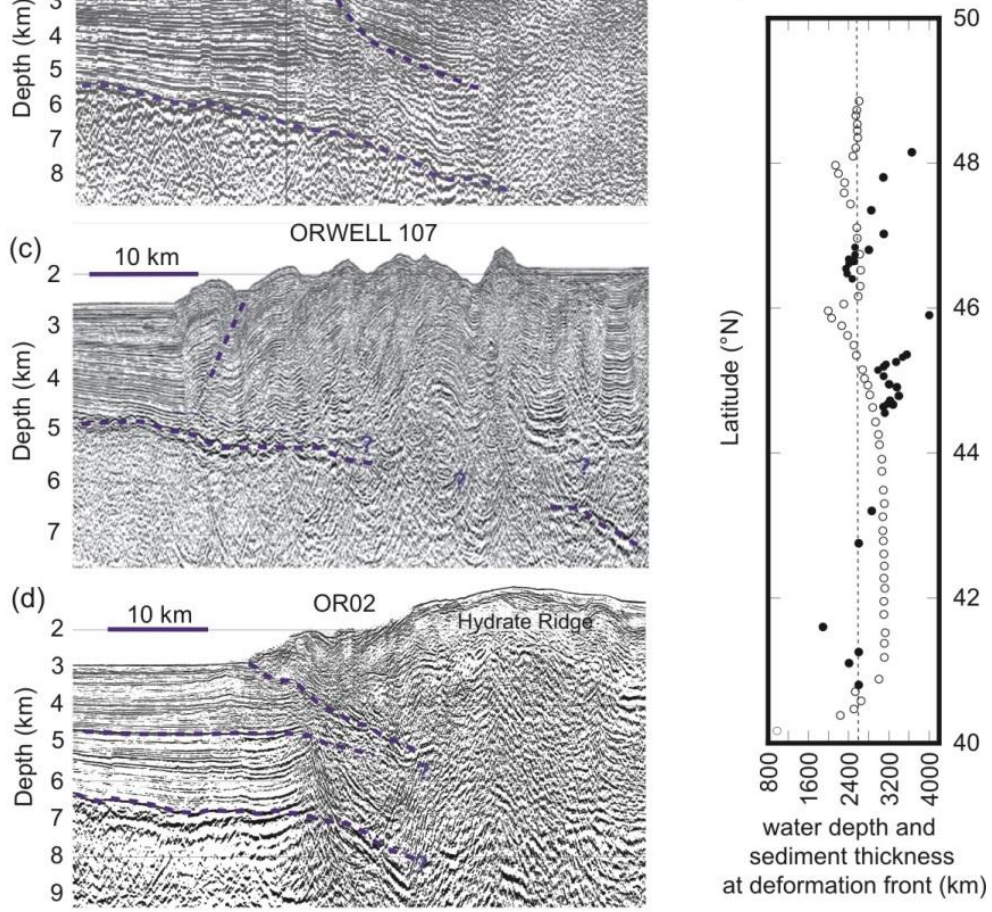

Fig. 6. Examples of fault structure near the Cascadia deformation front. (a) Topographic map of the Cascadia forearc. Light grey lines show the locations of crustal-scale seismic reflection profiles acquired between 1985 and 2012. White dashed line is the same as in Fig. 3. Seismic images indicate that the region outlined by a violet line is a broad plateau on the lower slope characterized by a series of mainly landward-verging folds and faults. This type of accretionary wedge structure is relatively rare. An example is shown in (c). (b) Seismic section from Fisher et al. (2006). (c) Seismic sections from the 1996 ORWELL experiment (e.g. Flueh et al., 1998; Booth-Rea et al., 2007). (d) Seismic section discussed by MacKay (1995) and converted to depth for this paper. The margin to the north and south of the violet-outlined area in (a) is narrower, and most profiles show a distinct seaward-verging frontal thrust as shown in (b) and (d). (e) Sediment thickness compiled from seismic reflection profiles available in publications or from the Academic Seismic Portal (ASP); a constant velocity of $2600 \mathrm{~m} / \mathrm{s}$ was assumed based on seismic refraction data from Tréhu et al. (1994) and Flueh et al. (1998) to calculate thickness from observed travel-times. Topography is from the Global Multi-Resolution Topography (GMRT) synthesis (Ryan et al., 2009) downloaded from http://www.geomapapp.org. 

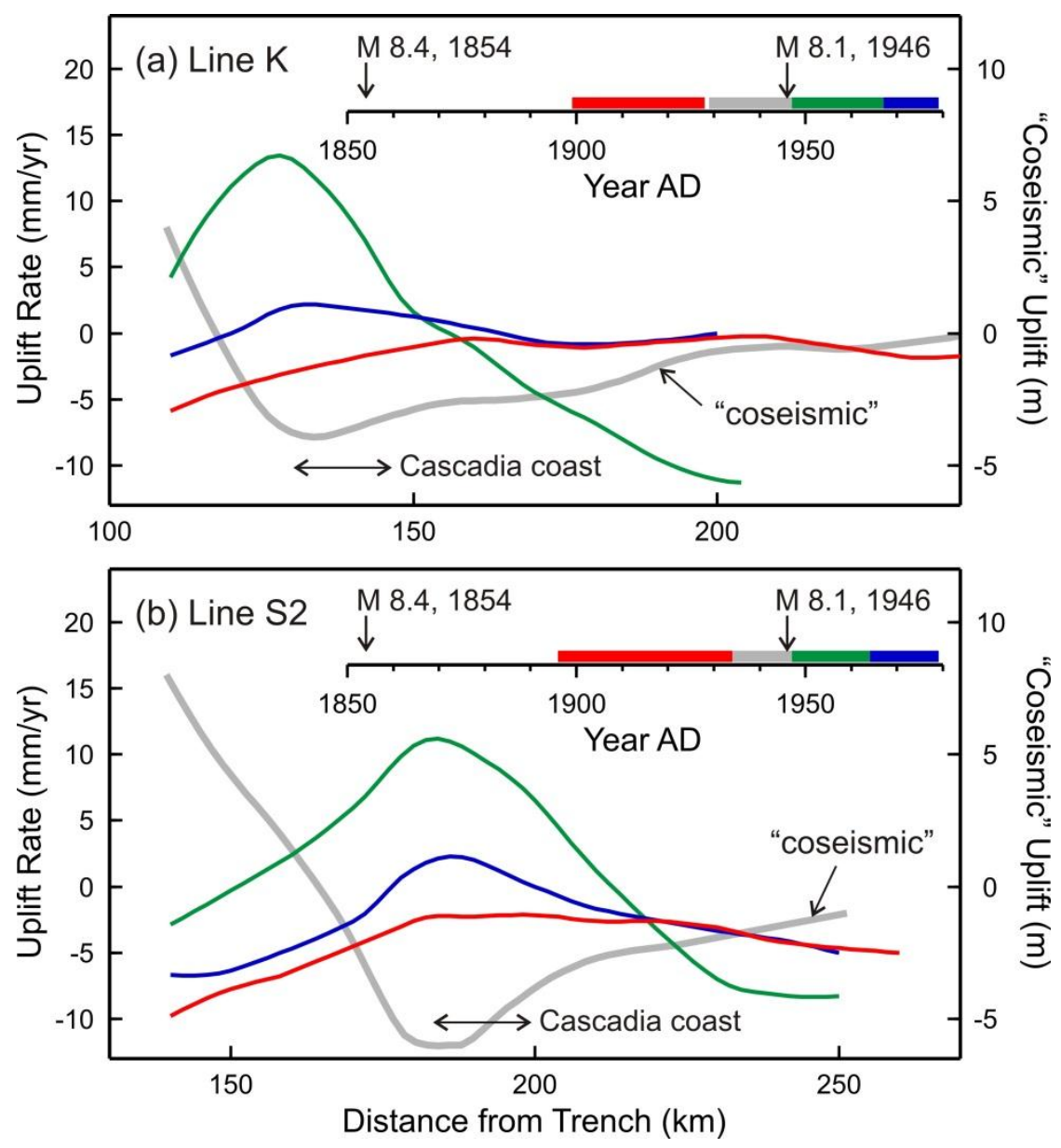

Fig. 7. Nankai leveling data over a subduction earthquake cycle based on Thatcher (1984), with survey time spans shown colour coded. Data have been hand-smoothed to accentuate longwavelength patterns. Both lines start from the coast (left end on figure). However, at Cascadia, the coast line would be located much farther landward as shown. (a) Line K (along west shore of Kii Peninsula), used by Thatcher and Rundle (1984) to represent the subduction earthquake deformation cycle in general. (b) Line S2 (through the island of Shikoku), used by Hyndman et al. (1995) and Hyndman and Wang (1995) for comparison with Cascadia. 

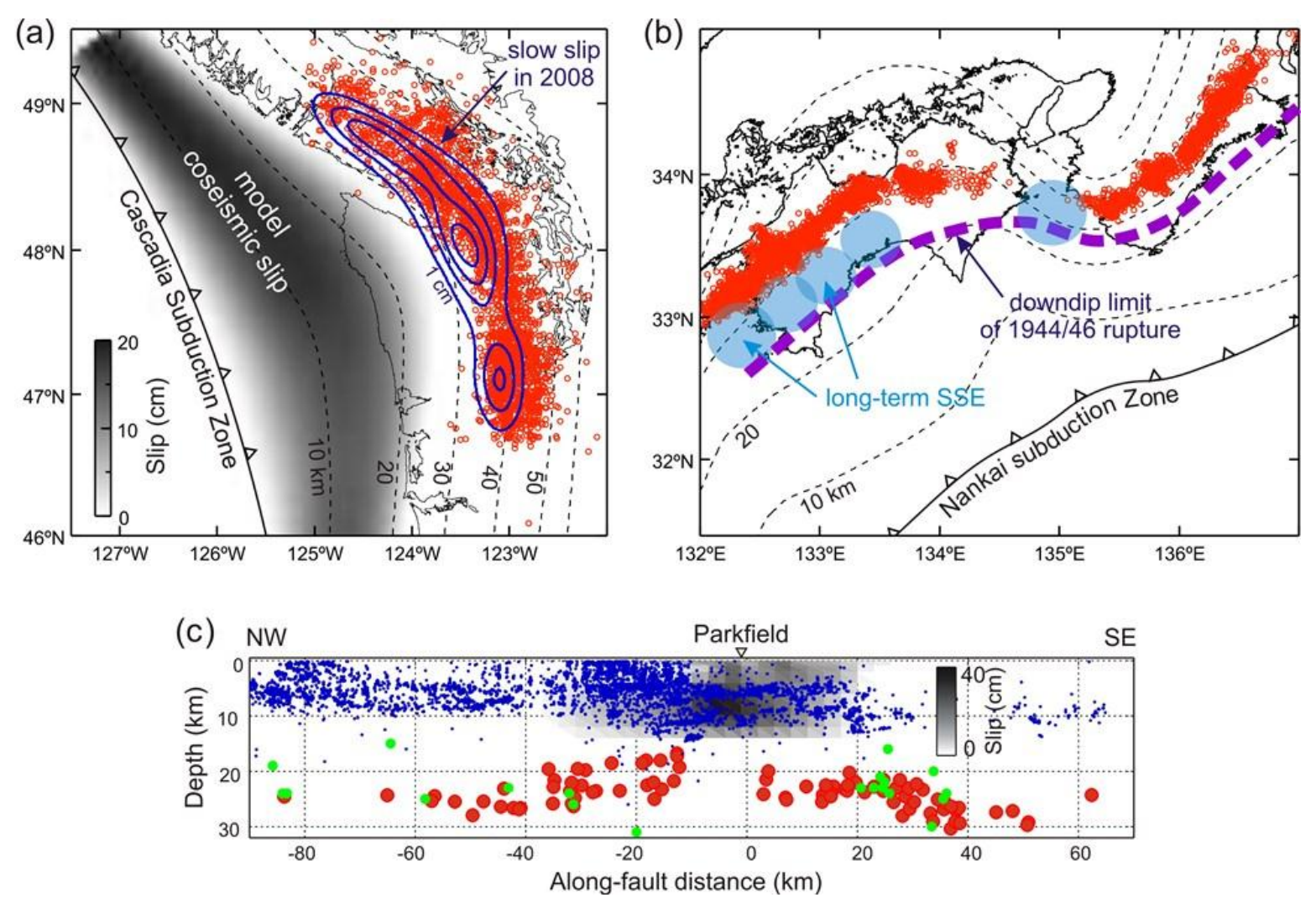

Fig. 8. Proposed and observed relationship between the seismogenic zone and the ETS zone. (a) Northern Cascadia. The coseismic rupture scenario is that of Fig. 2c. Tremor locations (red circles) and slow slip distribution (contoured at $1 \mathrm{~cm}$ interval) for the 2008 ETS episode are as shown in Dragert and Wang (2011). Dashed lines are depth contours of the plate interface (McCrory et al., 2004). (b) Nankai. The downdip rupture limit of the 1944/1946 $\mathrm{M}_{\mathrm{w}} \sim 8.2$ megathrust earthquakes is based on Ichinose et al. (2003), Baba and Cummins (2005), and Baba et al. (2006). Tremors (red circles) are from the period of 2004-2005; this pattern has been stable to date. Short-term slow slip events occur along the tremor band (e.g., Sekine et al., 2010). Locations of long-term slow slip events are based on (from west to east) Ozawa et al. (2013), Takagi et al. (2016), and Kobayashi (2010, 2012, 2014). Thin dashed lines are depth contours of the plate interface (Wang et al., 2004). (c) San Andreas Fault (modified from Shelly and Hardebeck, 2010), where no geodetically resolvable slow slip accompanying tremor has been reported. The shading shows the area of combined coseismic slip of the $2004 \mathrm{M}=6$ Parkfield earthquake and first 230 days of postseismic slip (Murray and Langbein 2006). Blue dots represent the hypocenters of regular earthquakes. Red and green circles are ambient and teleseismically triggered tremors from Waldhauser and Schaff (2008) and Peng et al. (2009), respectively. The Moho depth is about $25 \mathrm{~km}$. 
(a) the Japan view

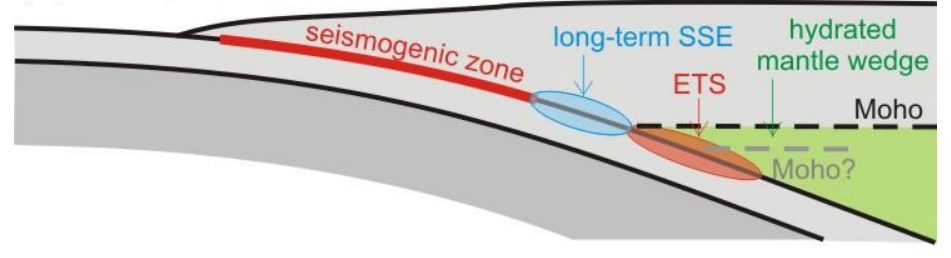

(b) a North America view

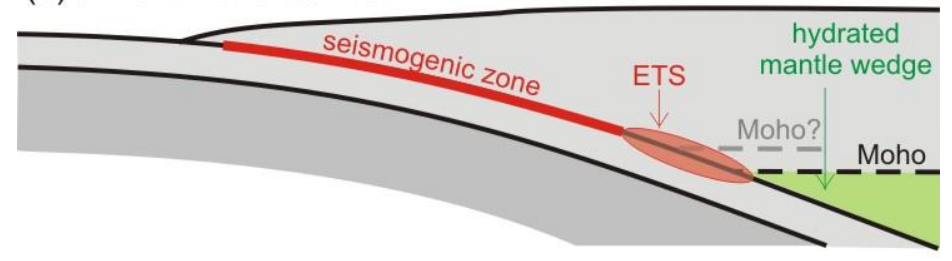

(c) a hybrid view

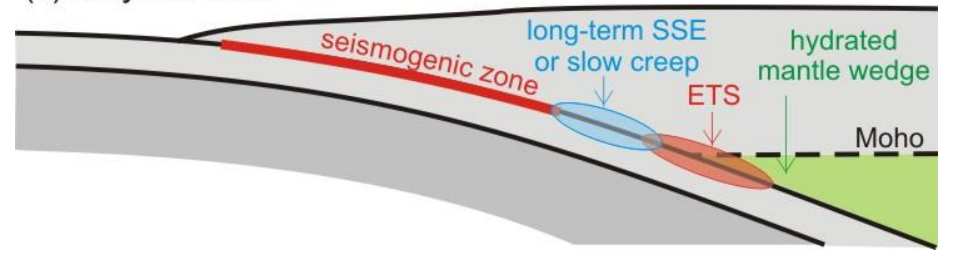

Fig. 9. Different proposals for the relation of ETS with the mantle wedge corner. (a) The commonly held view in Japan based on studies of the Nankai subduction zone (e.g., Obara, 2011; Kato et al., 2010), in which the ETS zone (the zone of tremor and short-term slow slip) is downdip of the mantle wedge corner. (b) A widely referenced view in North America (Audet et al., 2009; Peng and Gomberg, 2010), in which the ETS zone is entirely updip of the wedge corner. (c) A hybrid view that is consistent with observations from several subduction zones (Wang and Gao, 2016). 


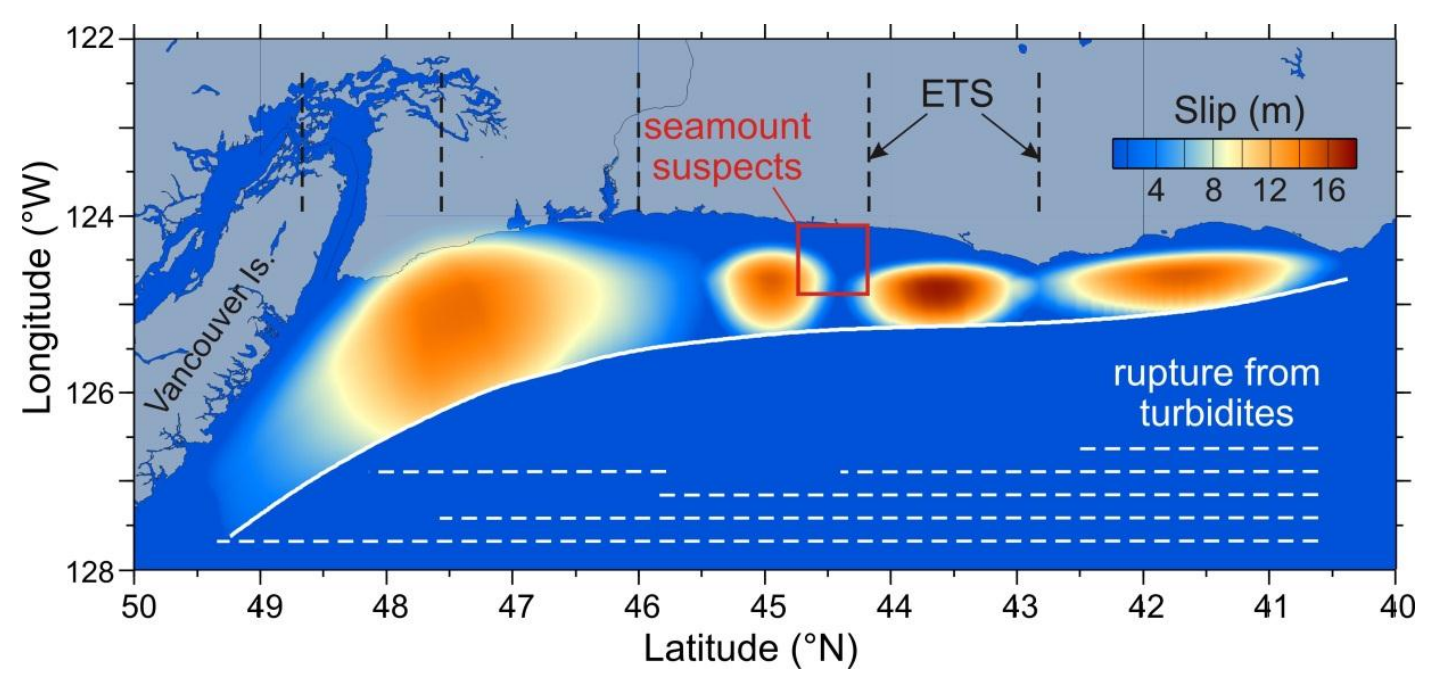

Fig. 10. Proposed variations in megathrust slip behaviour along the Cascadia margin. Estimated megathrust slip in AD 1700 earthquake is based on microfossil studies of coseismic coastal subsidence (Wang et al., 2013). Red box is the area of earthquake clusters and suspected seamounts (Tréhu et al., 2012) as shown in Fig. 3. Black dashed lines are segment boundaries of ETS activity from Brudzinski and Allen (2007), more or less consistent with offshore forearc basin distribution (Wells et al., 2003). White dashed lines indicate rupture extents of past Cascadia megathrust earthquakes based on analyses of turbidity deposits. These are the most recent estimates from C. Goldfinger (pers. comm., 2015) modified from those in Goldfinger et al. (2012) using new data. Each line is an average of a number of events with variable lengths; rupture termination at the southern end of the subduction zone is not well defined. The southern area is thought to rupture more frequently but with less slip in each event. 